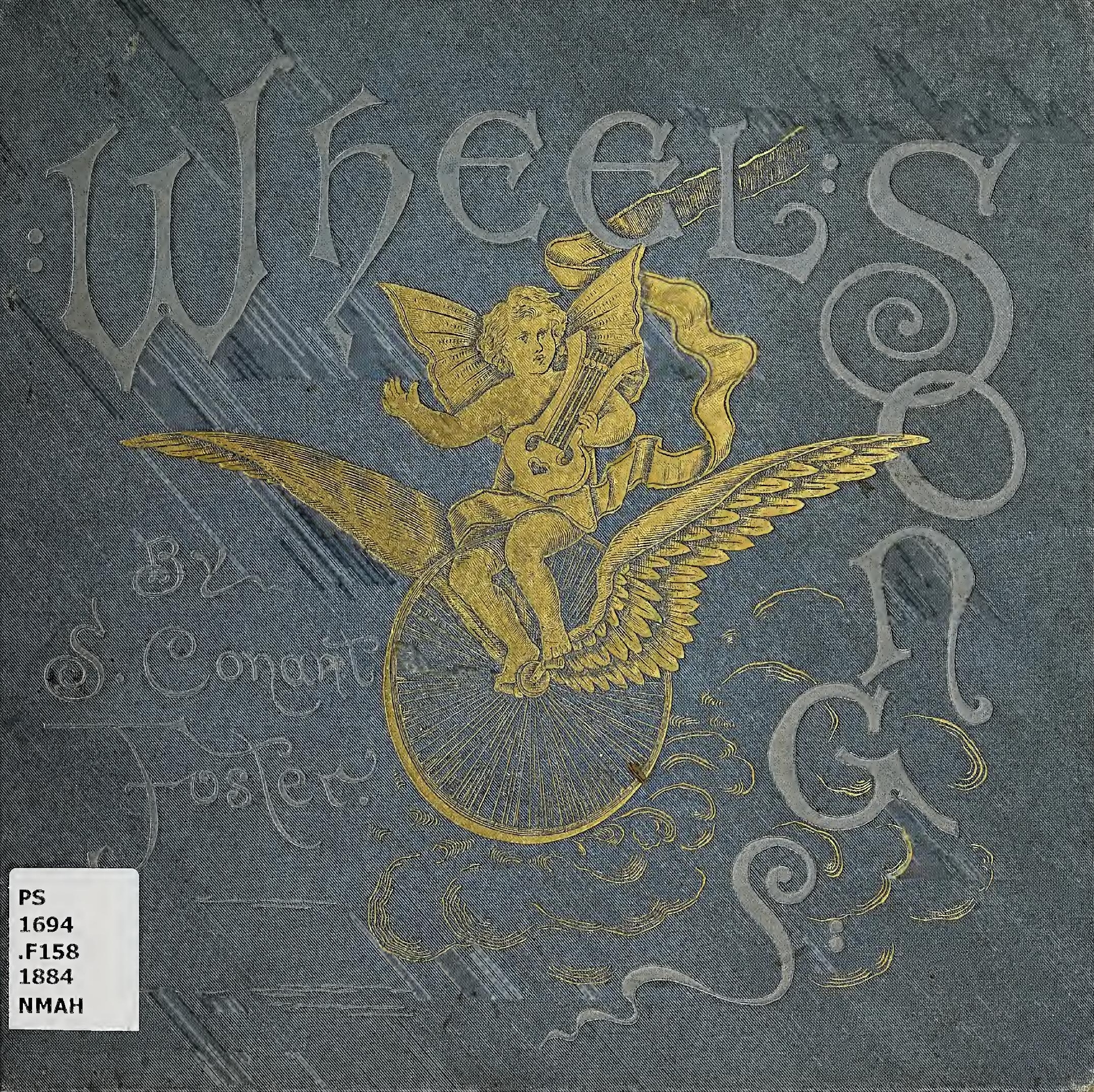





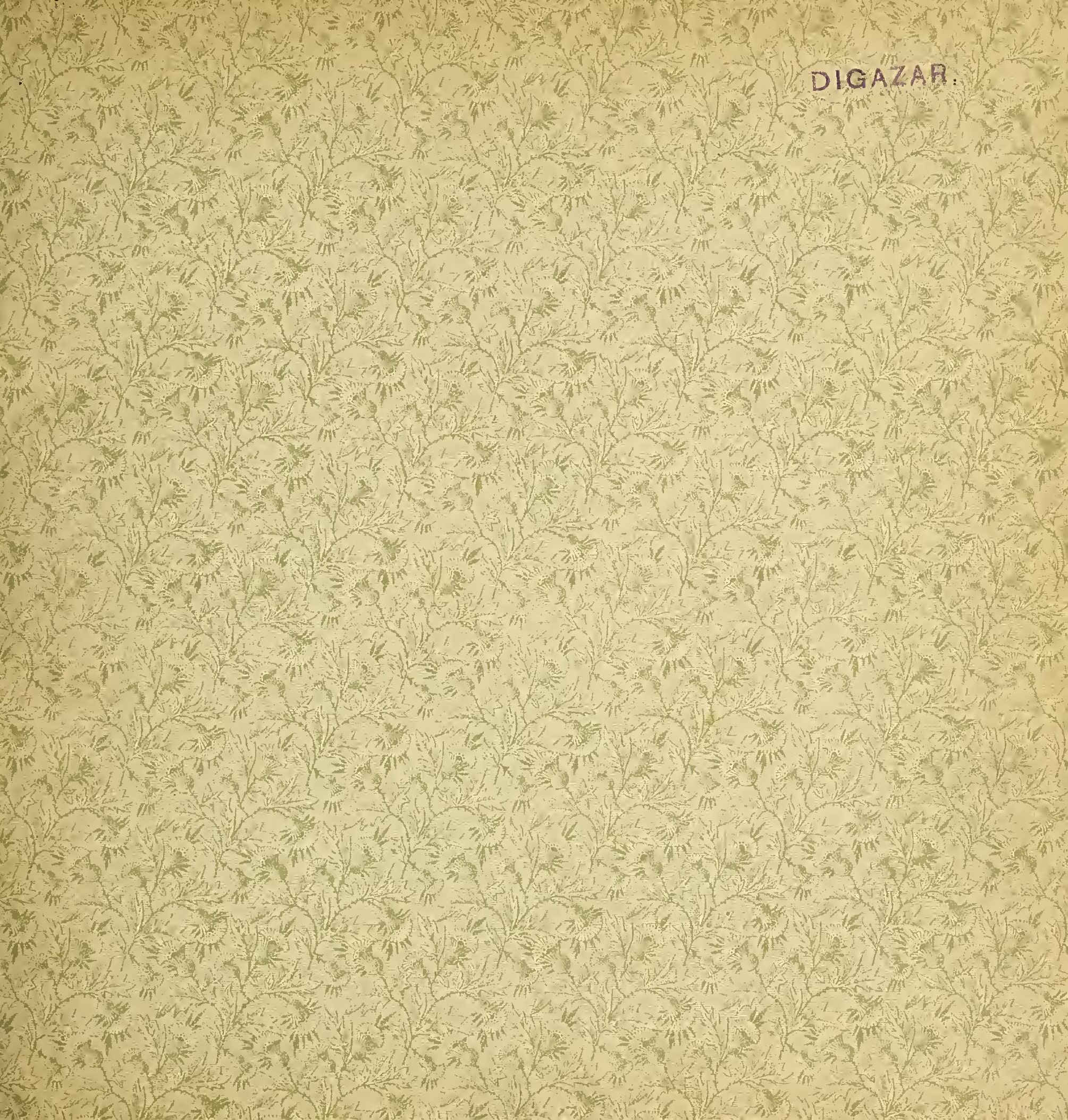





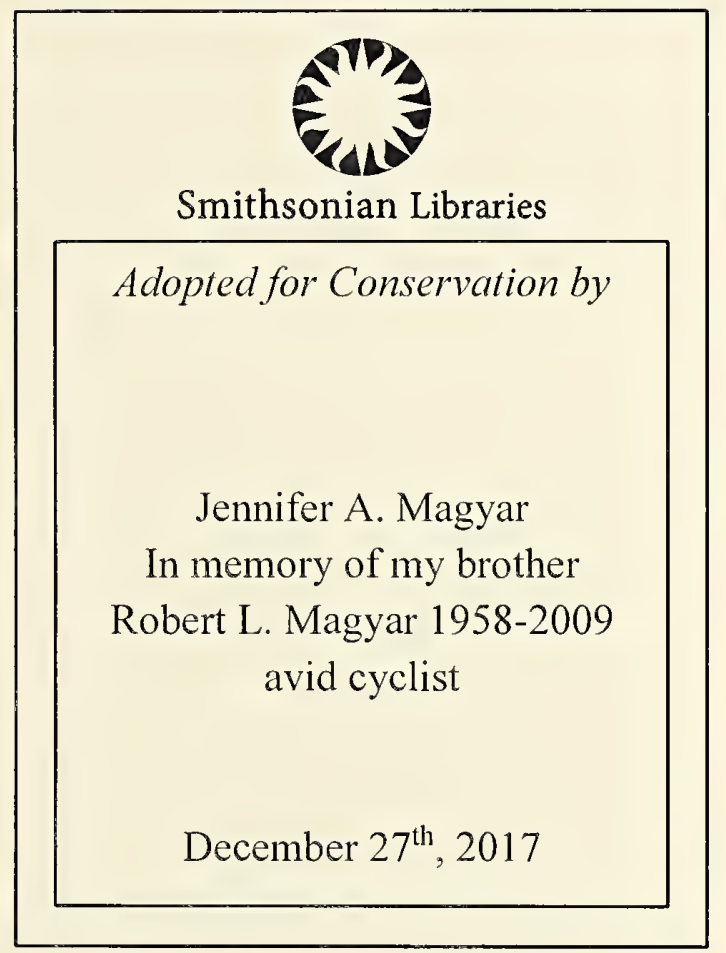





\section{WHEEL SONGS}

POEMS OF BICYCLING

BY

S. CONANT FOSTER

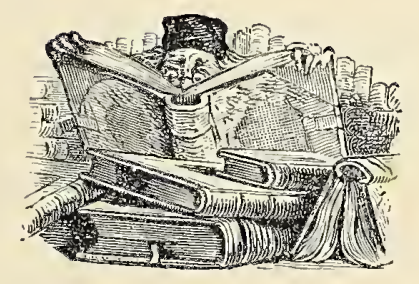

NEW YORK

WHITE, STOKES, \& ALLEN

I 884. 
Copyright $: 884$, BY

WHITE, STOKES, \& ALLEN 


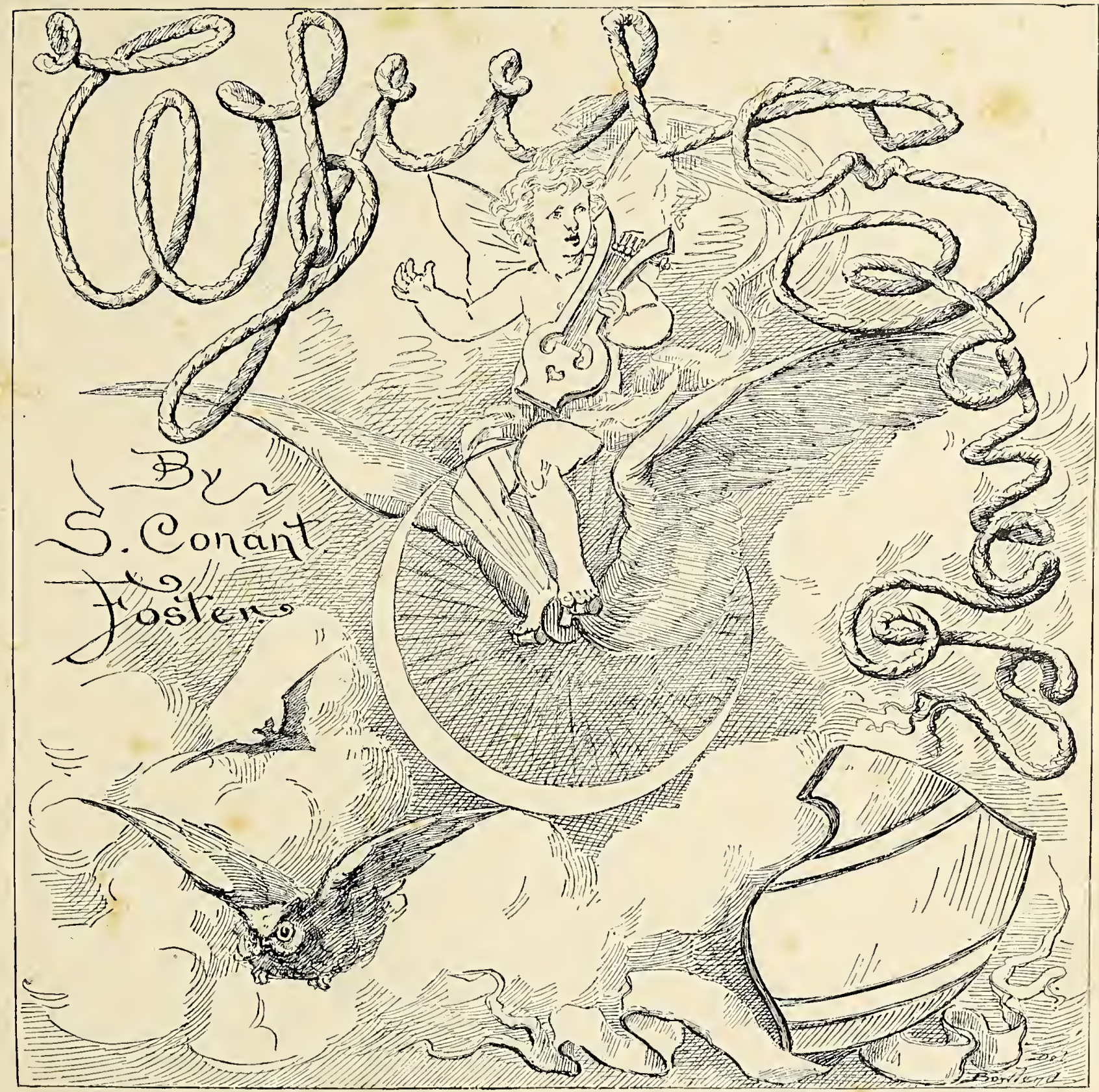





\section{Contents.}

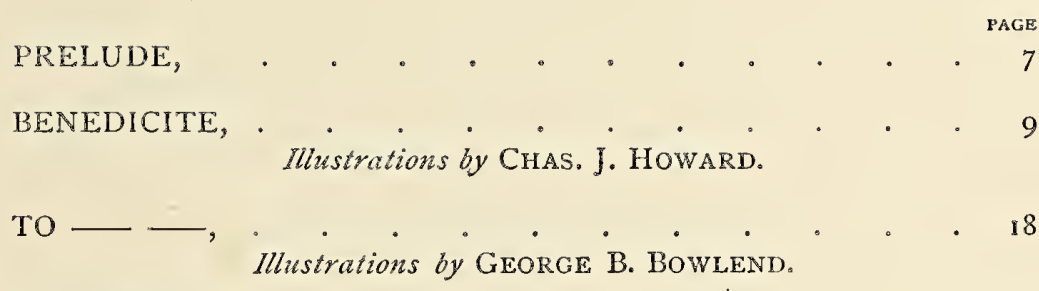

AN EPISTLE, . • • • . . . . . . . 19 Illustration by HENRY STULL; ail-piece by JAS. BUCHAN, JR.

TOASTING SONG, . . . . . . . . . . 27

Illistration by GEORGE B. BOWLEND.

A MIDNIGHT RIDE, • • • • • • • . . 29

A MIDWINTER REVERIE, • . . . . . . . 33

Illustration by $\mathrm{F}$. CHILDE HASSAM.

ON WINGS OF LOVE, • • • . . . . . . 36 Illustrations by GEORGE B. BUWLEND.

WHEEL BLISS, . • • . . . . • . . . 40

Illustrations by C. J. HOWARD and GEORGE B. BOWLEND.

IN MEMORIAM, illustrations by C. J. HOWARD. • • • 43

SONNETS-TO C. E. P., • • • • • . . . 47

TO MY BICYCLE, • . • • • • . 48

TO THE NEW YEAR, . . • . • . . 49 


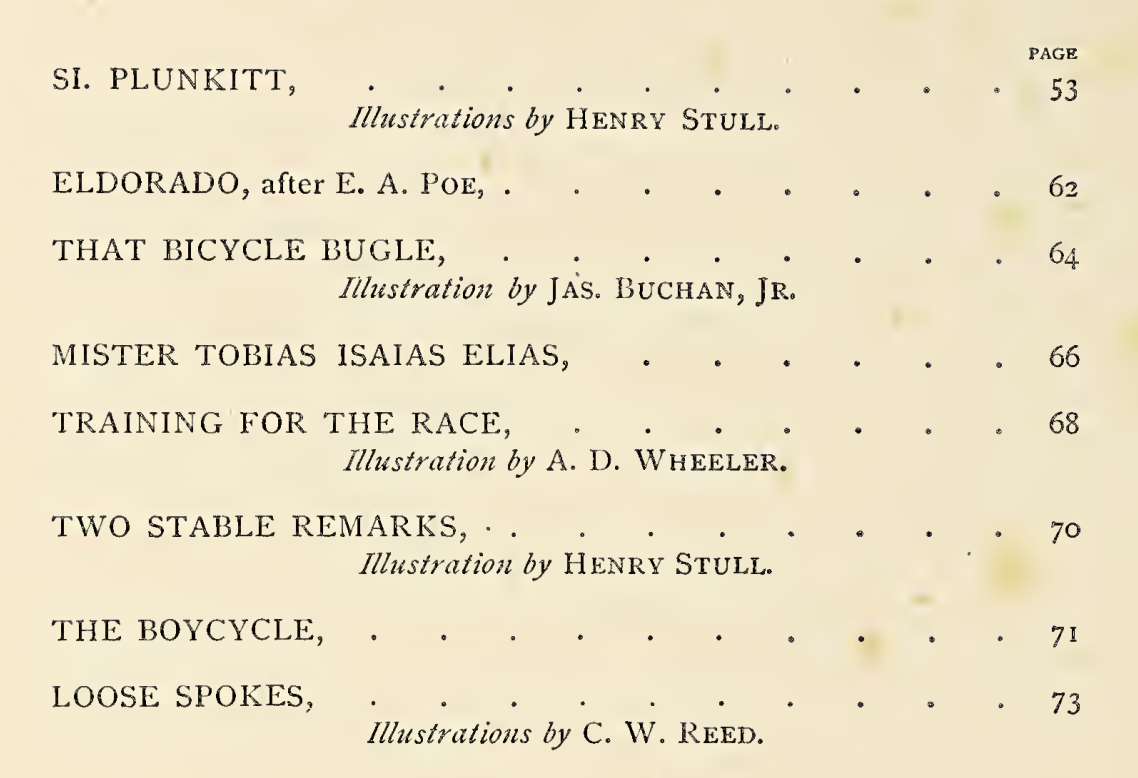




\section{Prelude.}

RE-ECHO ye walls and ye raftered roofs,

And voice it o'er vale and mountain,

That Pegasus, stamping his silver hoofs,

Has opened the singing fountain.

Each drop in delight of its rhymèd might

A song to our sport is waking,

And rainbows so bright in the soft sunlight,

The form of the wheel are taking.

Come! mount and away! Let the tuneful lay

Flow on to the treadle's timing;

Yet, tarry I pray - for a moment stay

And list to the waters rhyming.

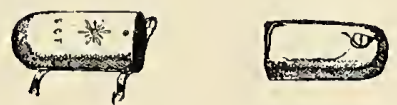





\section{Benedicite.}

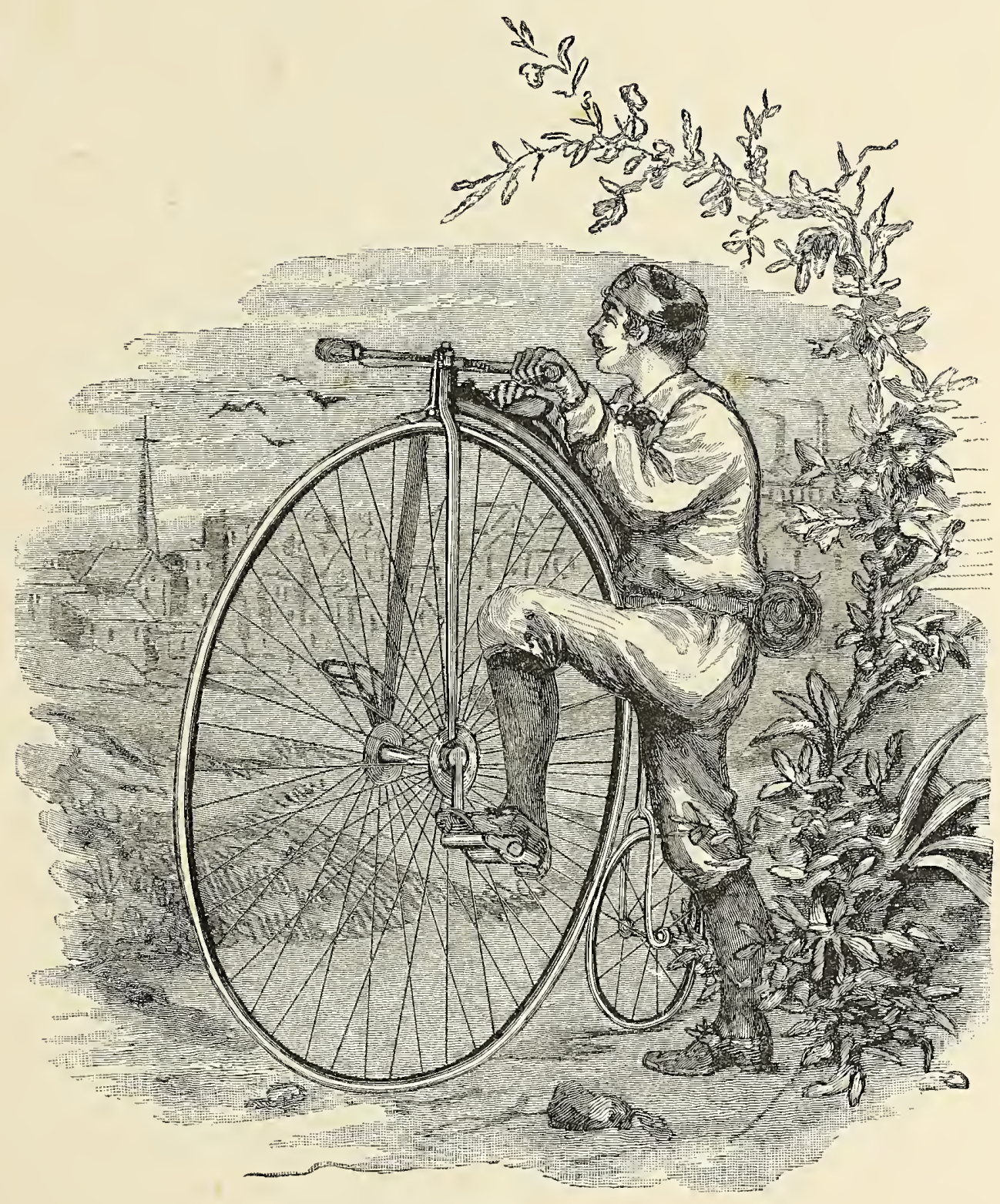

. . . an instant pauses at the gates,

An instant listens as the morning wakes

The din of life he leaves behind. 


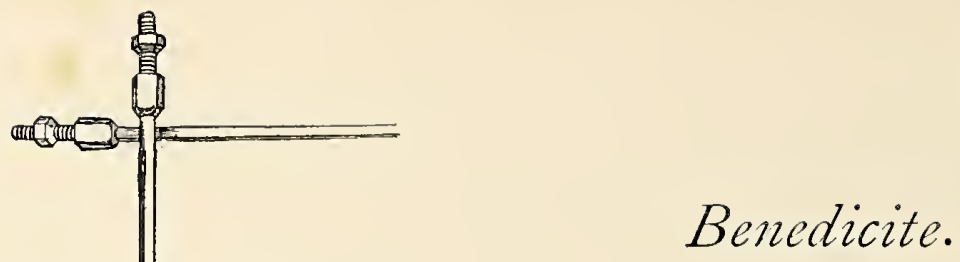

From out the heated city Cyclist takes

His way; an instant pauses at the gates,

An instant listens as the morning wakes

The din of life he leaves behind; then waits

No more, but with a cry of pleasure flees

To where his wheeling song may freely rise

On air more pure; where floats the sweetened breeze

Between the verdant fields and azure skies.

Through woody hollows carpeted with moss,

Up daisy-covered hills, o'er babbling brooks,

Down steep, uncertain paths, with vines across,

In sleep-enticing spots and ivied nooks,

Past cooling caves - from each to each he flies;

Now sinking deep amid some clover bed,

Now drinking crystal dew of summer skies

From out some lily cup above his head. 


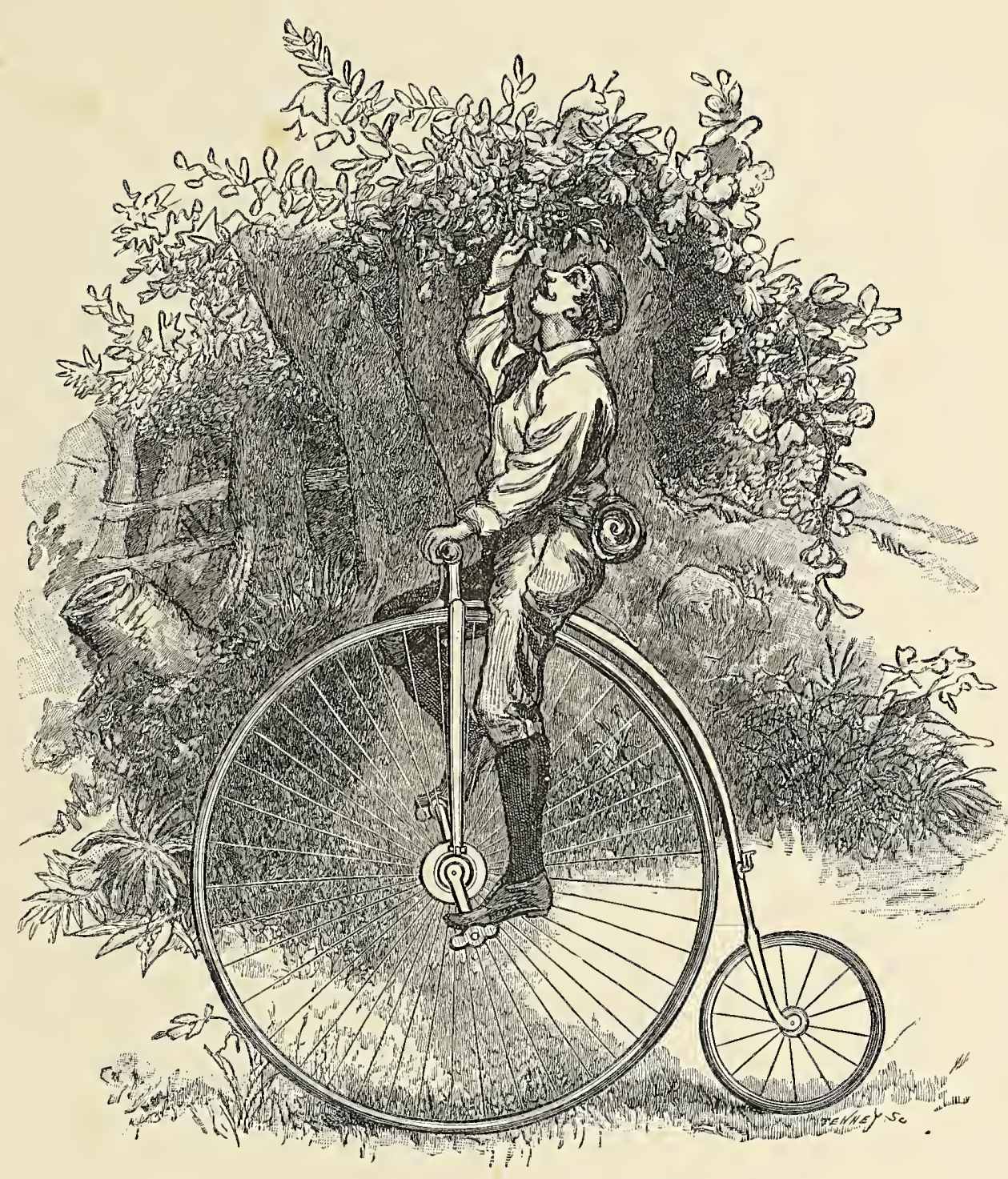

Nowe drinking crystal dew of summer skies

From out some lily cup above his head. 


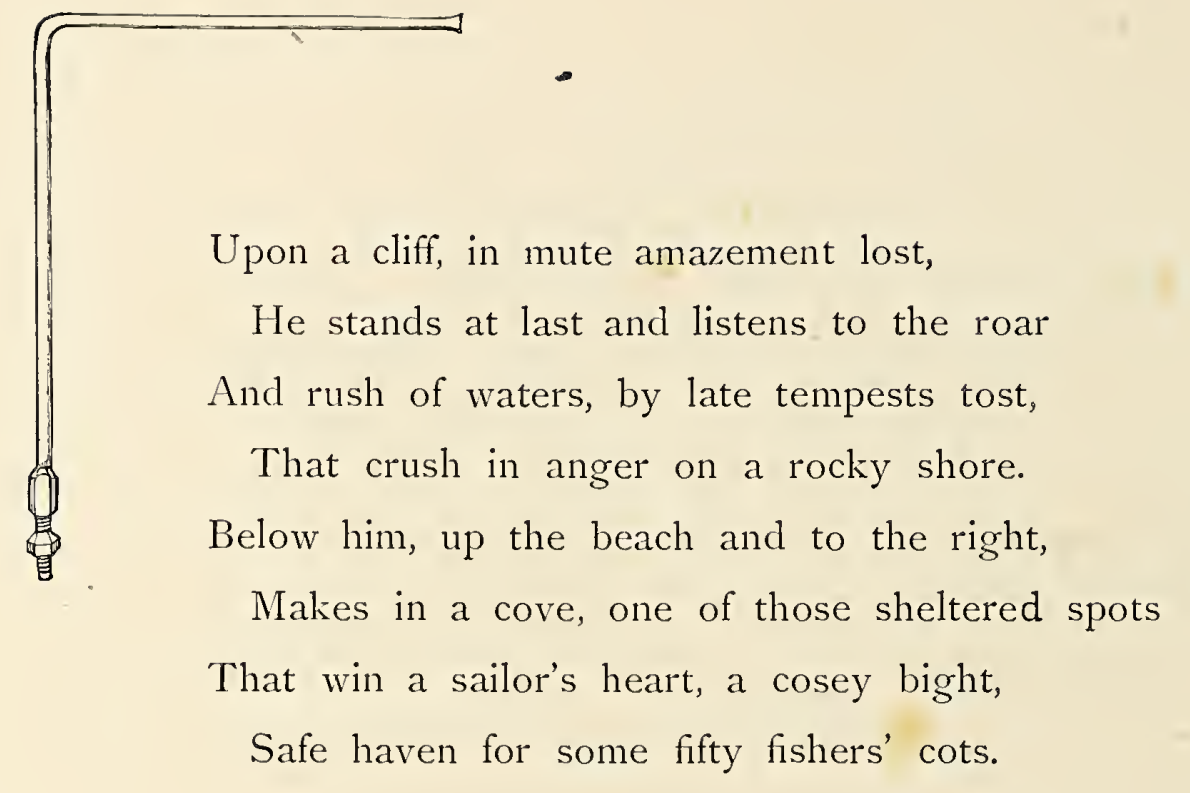

'Tis here, in this secluded fishing town, Where hollyhocks and china-asters grow Before the doorways weather-worn and brown, And o'er the shelly paths their petals strow, That wandering Cyclist, lulled by moaning sea And sighing wind, by stormy petrel's scream And flying mist, reposes 'neath the lea Of an embedded wreck and dreams his dream. 


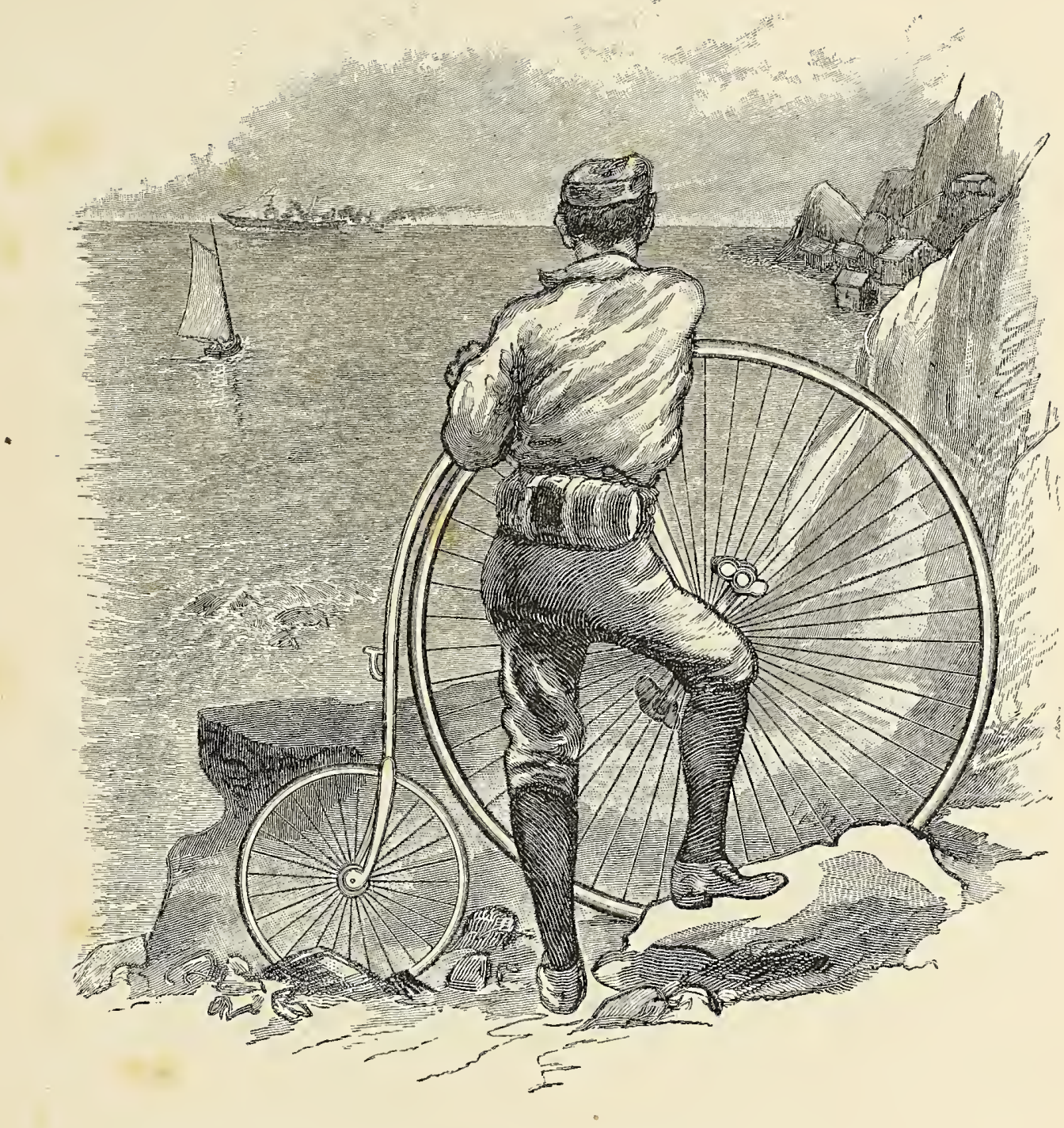

Upon a cliff, in mute amazement lost,

He stands at last and listens to the roar

And rush of waters . . . . . 
He sees a narrow street, to him well known,

Where busy men go rapidly along,

With woful care upon their faces shown;

And lo, he, too, is of the anxious throng

Of hurrying ones; a frown of fretting thought

Sits on his forehead and unrests his eye;

Anon he passes down a sultry court,

Then gains a heated office wearily.

All day without he hears the roar of trade,

Within the hum and noise of laboring clerks;

Below accounts lie waiting to be made;

And though the day is done, yet still he works;

Though temples throb, yet still within this den

He lingers on, companion of dull pain,

Till fingers guide no more the stubborn pen,

And on his desk he rests a weary brain. 


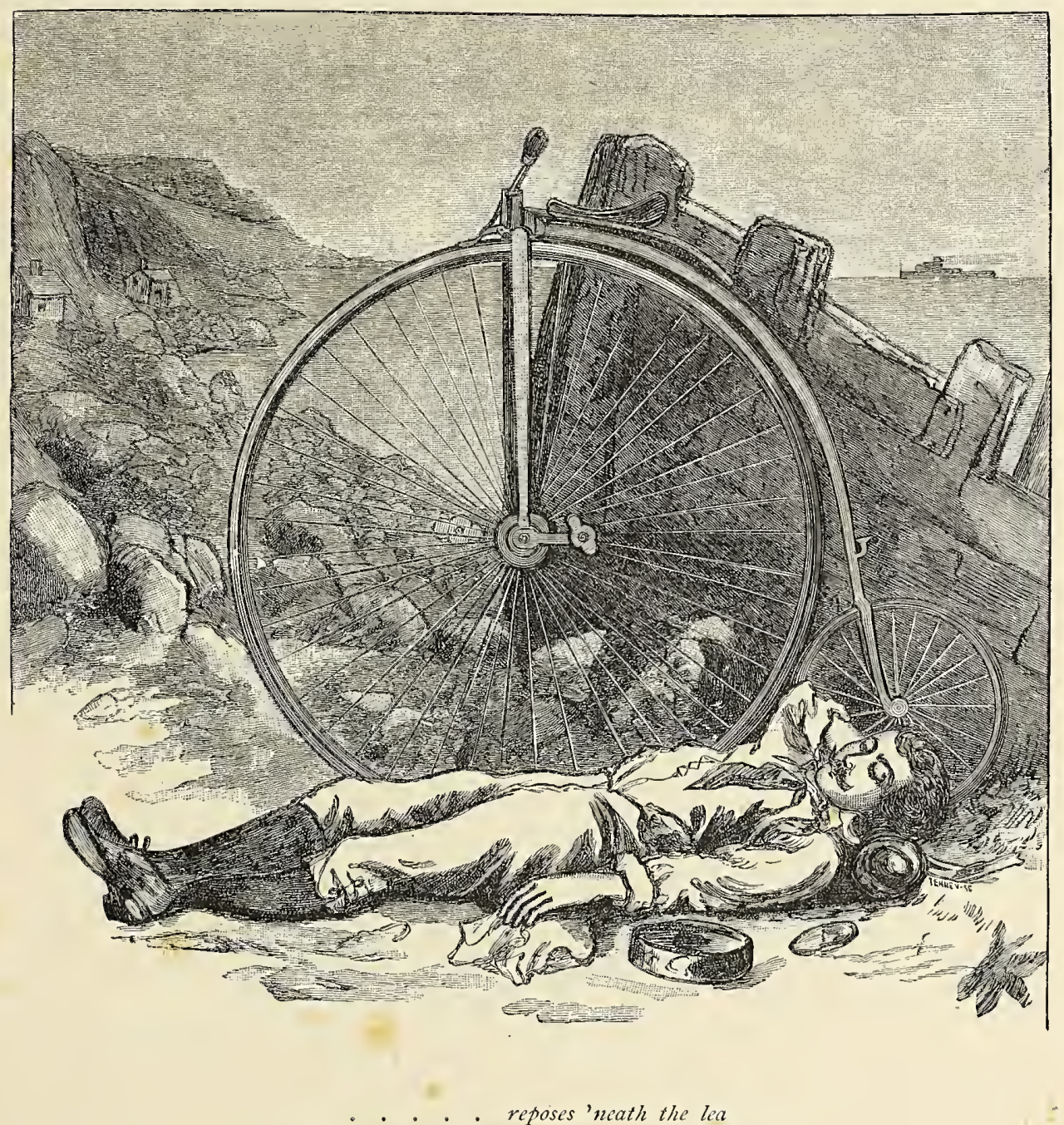

of an embedided wreck and dreams his dream. 


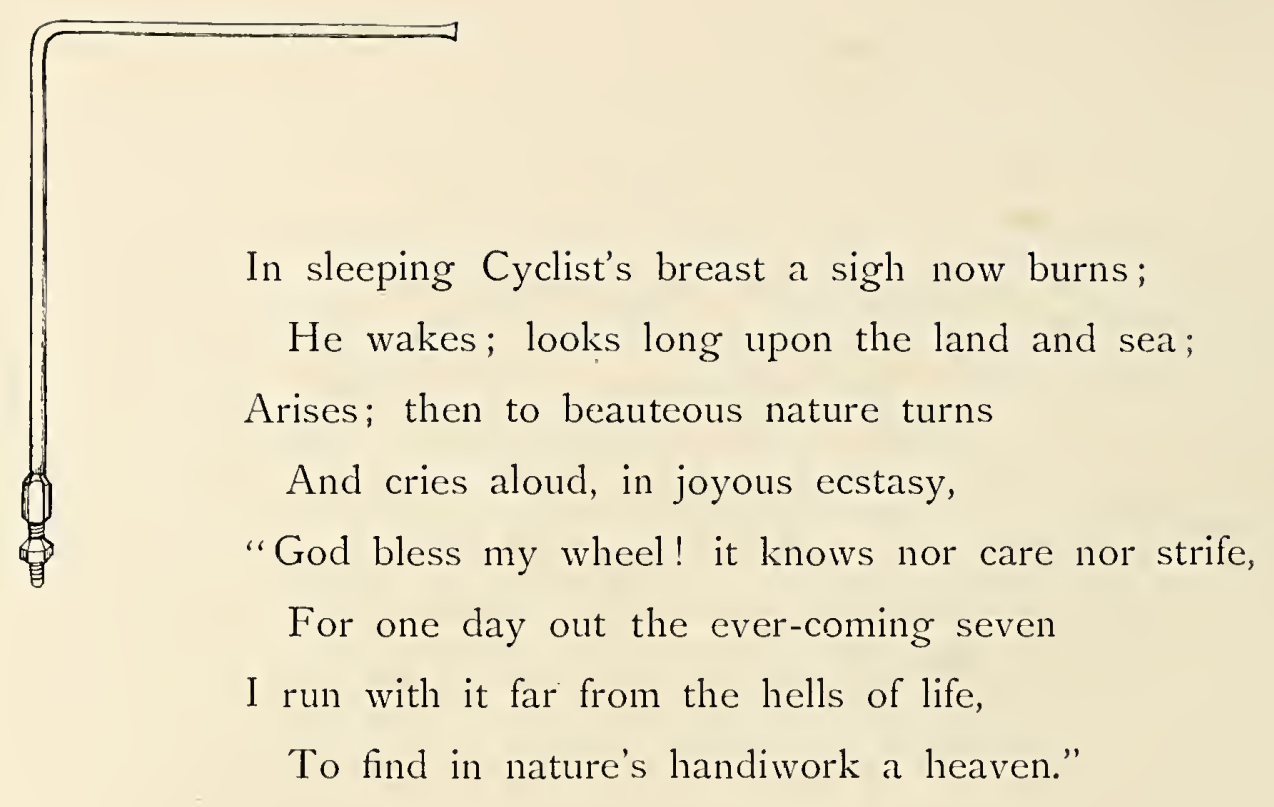

Now all is silent as the falling dew;

The sun has set; the moon, ascended high,

Doth light the slumbering earth with silvery hue;

A night-hawk gives his solitary cry,

Safe in the confines of the heavenly blue.

Again doth Cyclist leave his day of weal;

And, when the city's gates he passes through,

Once more with joy exclaims, "God bless my wheel!" 


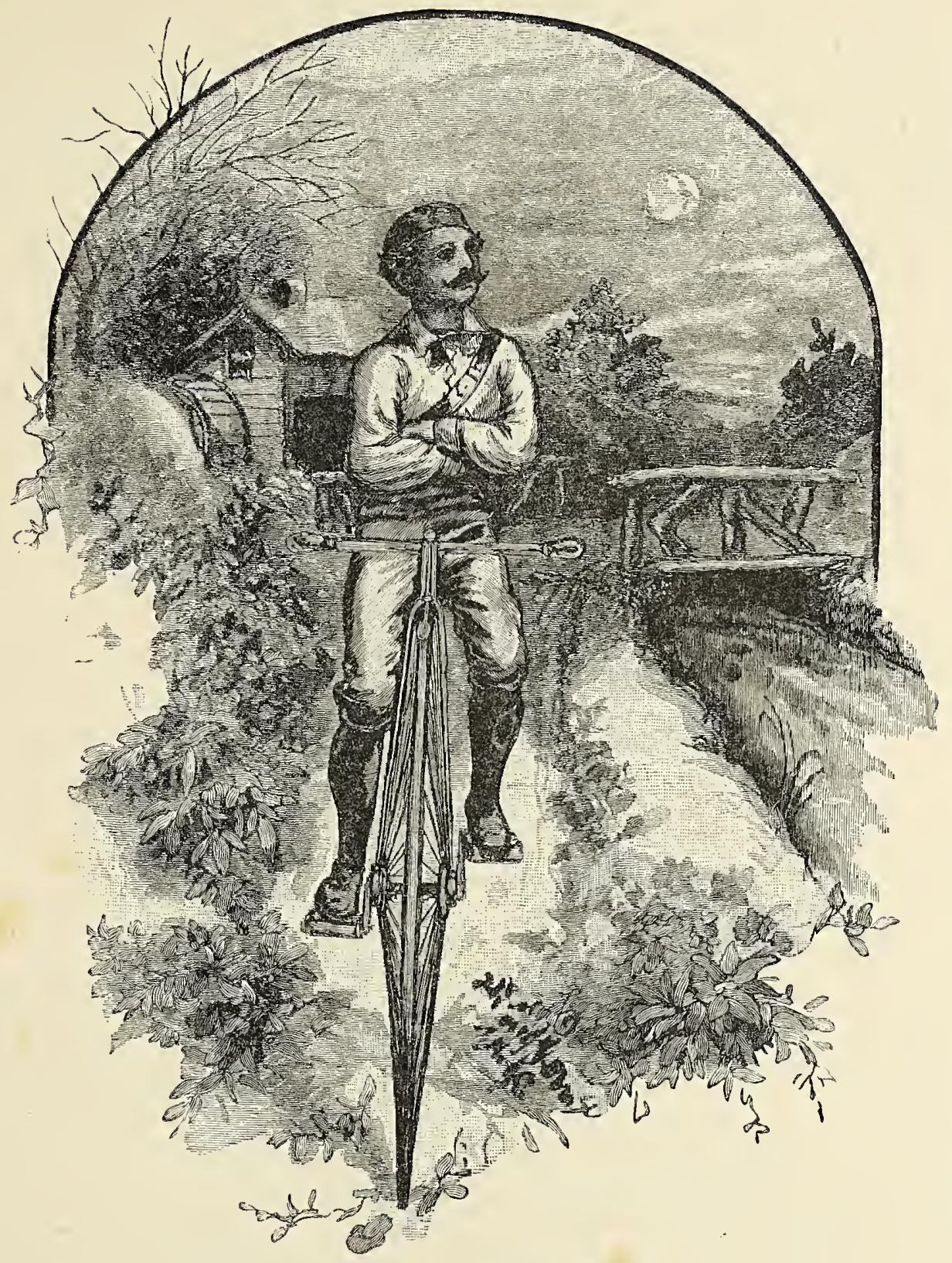

Now all is silent as the falling dew;

The sun has set; the moon, ascended high,

Doth light the shmbering earth with silvery hue. 


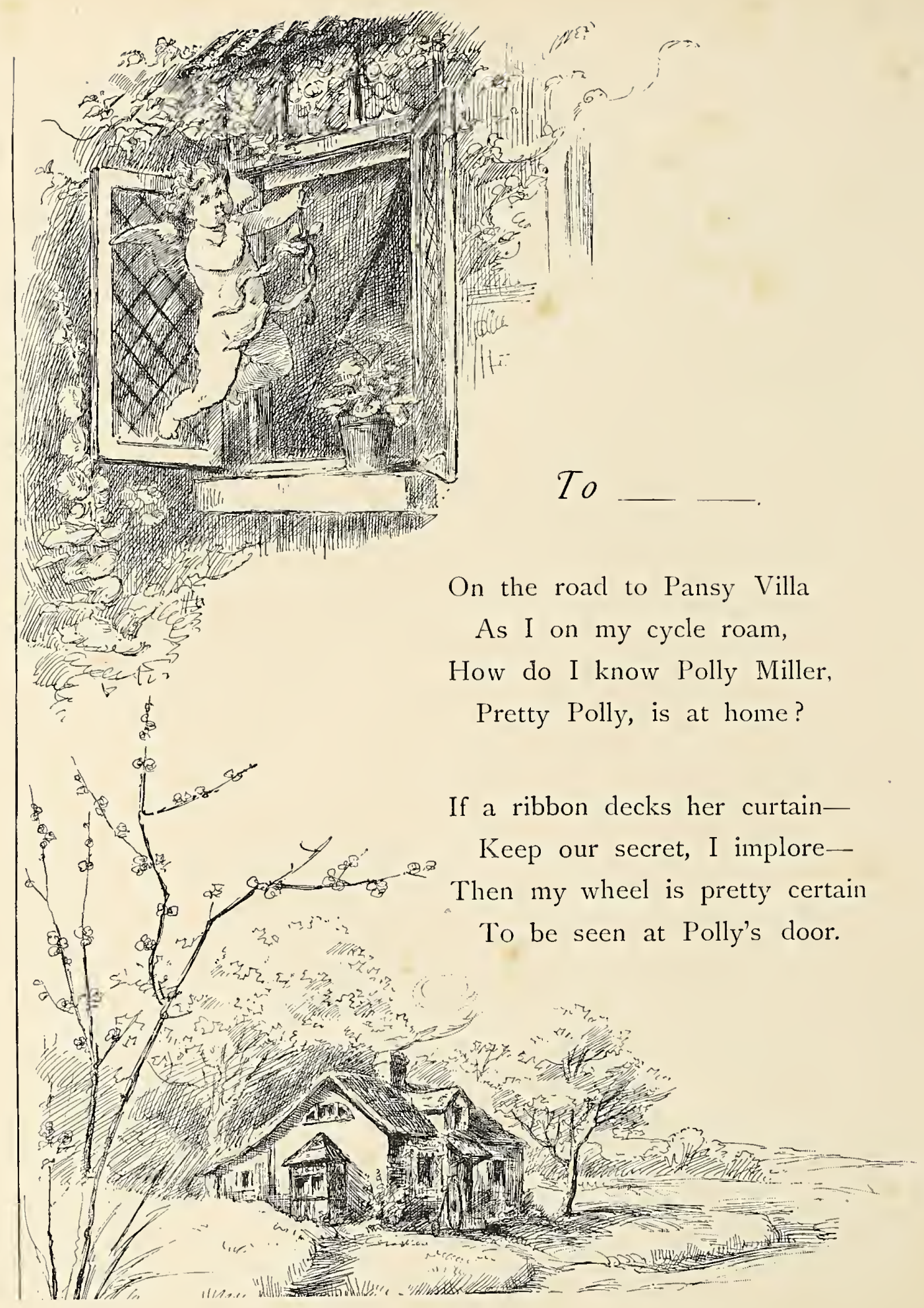




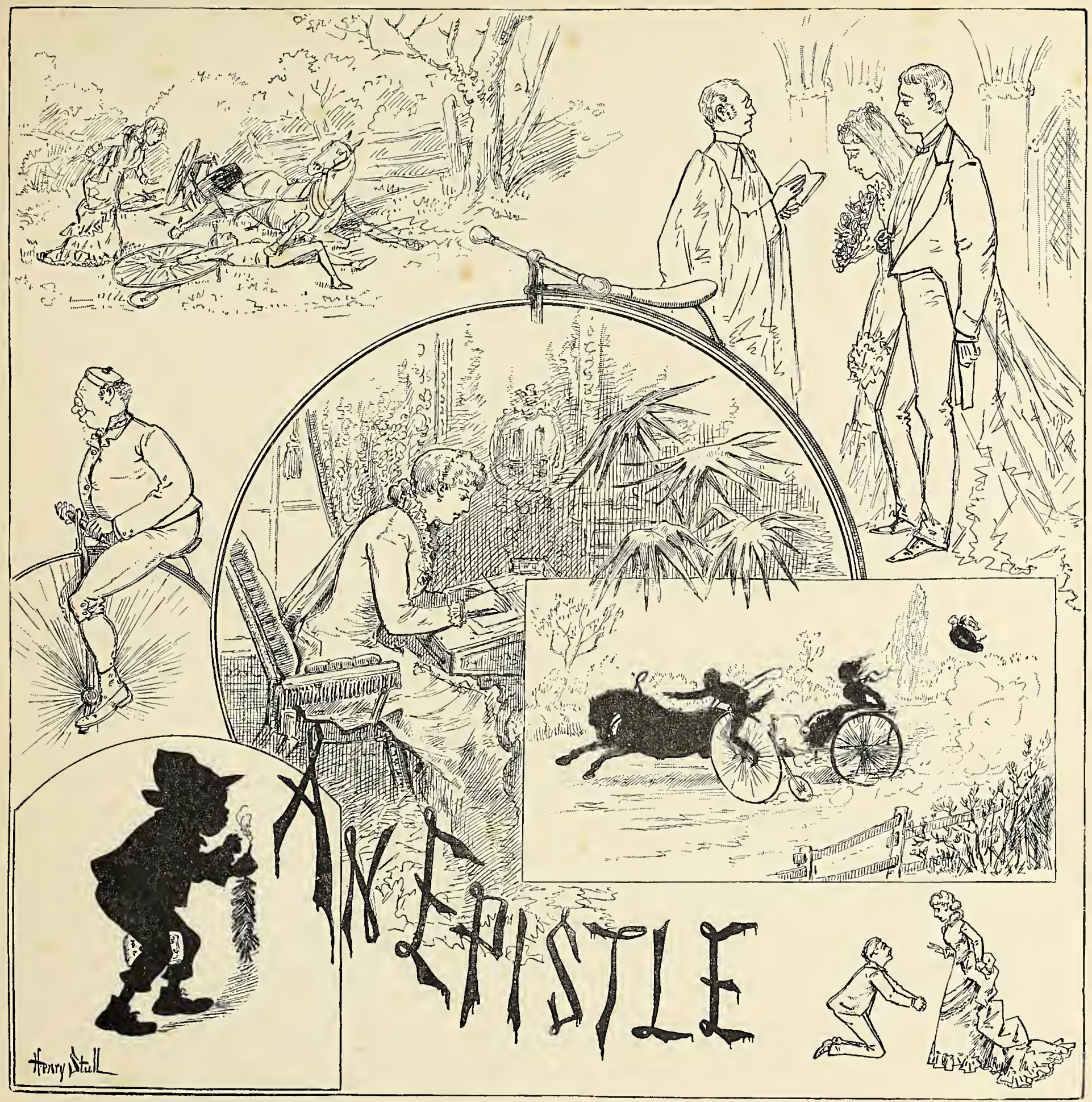




\section{An Epistle.}

\section{Dear Cousin Louise:}

\section{I confess to neglecting}

Your note under date of July; but reflecting

On all I've performed, and on all I'm projecting,

It's a wonder to me I've no bee in my bonnet,

And am still compos mentis to comment upon it.

Now, what do you think? I am going to marry!

The photo. I send you with this is my Harry.

He's awfully handsome! I'm sure, my dear Coz.,

You'll like him immensely, as every one does.

He's so noble and brave, and so splendidly muscled,

He reminds me of those clever fellows who tussled

In Rome, don't you know? with such doughty demeanors

In th' What-do-you-call-'em? Oh, yes, the arenas.

Of course you are dying to know how we met:

Ah! Lu, it's a thing I can never forget;

So romantic - so - well, I've no leisure for gushing,

I expect him at three, and the moments are rushing, 
So judge for yourself. I am sure you remember The pony I teased from Papa in December,

And the cart he bestowed without asking, - the dear!

On condition I'd try not to flirt for a year? Well, while driving along on the $4^{\text {th }}$ of July,

A contemptible, mischievous urchin let fly

A cracker. I instantly evil foreboded.

It sizzled a second, then stopped, then exploded.

The pony, with ears pricking forward in fright,

Stood trembling a moment-next danced to the right -

Then away went his heels - crack! the whiffletree parted,

And, with teeth clutching bit, Deuteronomy started.

Well, I yanked, and I pulled till I thought I should drop,

I forgot to say Whoa! so I shouted out "Stop!" Which of course showed the wretch I was out of my senses,

And away we went flying by trees and by fences. And away went my beautiful Gainsborough hat, Forty dollars, my dear, - but I didn't mind that, For the brute at each step was now galloping bolder, As if bent upon jerking my arms from the shoulder.
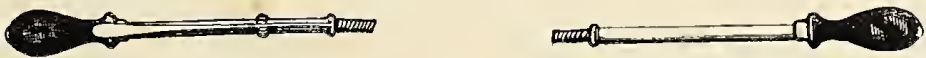
On a sudden he turned down the road to the river.

It's impossible, $\mathrm{Lu}$, to describe the cold shiver

That ran over my back. I was thoroughly scared,

For the bridge at the channel was being repaired.

I remembered a gap at the draw, and despaired.

I endeavored to fancy myself an Elaine

Floating sweetly along on the tide, but in vain:

I could only see eels, and such horrible creatures,

Making nibbling attacks on my classical features;

So dropping the reins - and I might have done rasher-

And bracing my feet at the foot of the dasher,

I fast to the sides of the village cart held,

And did as most any weak woman would - yelled.

"Do be still," said a voice, and my heart gave a bound,

It was close to my ear, yet I heard not a sound, And, not daring to turn, I was left in the dark As to who had expressed such a silly remark.

Now, imagine, dear Coz., if you'd have your teeth chatter,

Deuteronomy's feet on the bridge in a clatter, The whip, and the blanket, and half of the load (The wrong half, you know), lying back on the road, 
And a sheet of dark, swift-running water before,

Looking black as a grave through the hole in the draw.

I was griping the sides with the grip of a vise,

And so cold, oh, so cold, like a figure of ice,

While King Terror was thumping big thumps on my heart,

When a man on a bicycle dashed by the cart.

It was done like a flash. With a shout and a leap

He had captured the horse, and we lay in a heap.

I was up on my feet in an instant, unhurt.

Such a sight as I saw! In the débris and dirt

Lay the pony quite still, as if glad of the rest,

But, alas! with a hoof on the gentleman's breast.

He was pale as a ghost, with a bruise on his brow

(It's the gentleman, Lu, I an speaking of now).

In a jiffy I had the poor fellow extracted.

There was blood on his lips; I was nearly distracted, And cried, like a goose, "He is dead! He is dead!"

He struggled for breath - he had heard what I said "Not quite, Mistress Gilpin;" then down flopped his head.

Did you ever hear anything quite so provoking?

First to struggle for breath, then to waste it in joking. 
I was utterly helpless, so sat there and trembled Till the usual number of farm folk assembled.

Of the slow fourney home let me skip the details:

How they carried him back on a litter of rails, And how it took cooky, the coachman, and groom

To get him ensconced in our pretty spare room. He'd received quite a shock, Dr. Simonson said, A contusion, or something like that, on the head, And a blood-vessel ruptured. Oh, dear, such a week!

He was out of his senses; did nothing but speak

Of runaway teams and his racing behind,

Till I was convinced when he did get his mind

The very first word that he'd utter would be

The fondest of queries, Louise - after me.

Then conjecture how rudely my feelings were dashed When he simply remarked: "Was the bicycle smashed?"

It was, all to bits, but Papa got another,

A Semi-Pope-Harvard, or something or other, And would you believe it, one, too, for himself. Yes, Dixie, his trotter, is quite on the shelf; Just stamps in his stall, and does nothing but squeal, While $\mathrm{Pa}$ is enjoying himself on the wheel. 
It is funny, Louise (this I ought not to mention),

$\mathrm{He}$ at one time declared 'em the devil's invention.

Such a radical change! But the thing the most rich is

To behold his extremities rigged in knee-breeches.

It's just striking three, and I hear Harry's whistle,

Which means I must close this protracted epistle.

I thought to be able to tell ere I stopped

The horrible manner in which Harry popped;

Just blurted it out without preface or warning.

(I made him propose, as he should, in the morning,

Just as Algernon Mandeville did in the book,

On his knees, don't you know? with an agonized look.)

He's so void of romance; I was dreadfully vexed;

But I'll give you the whole, word for: word, in my next.

Let me close, then, Louise, with a hug and a kiss.

I expect to receive a long answer to this.

Good-by. Love to all. Write as soon as you can.

Your own loving Cousin,

Winona Bevan.
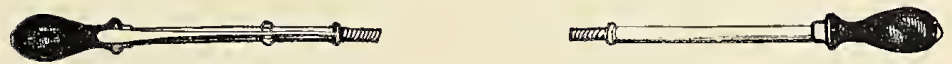
P.S. :

Harry told me to-day he had bought me a "trike." Being perfectly ignorant what it was like, I blushed, for he said 'twas intended for two;

I thought of a cradle at once, wouldn't you? It's a tricycle, dear. Please omit the above

If you read this aloud. With my kisses and love I bid you, dear cousin, a second farewell. My trousscau is just too-too-utterly swell, And some of my presents are gorgeous to see.

Yours truly and lovingly,

W. B.

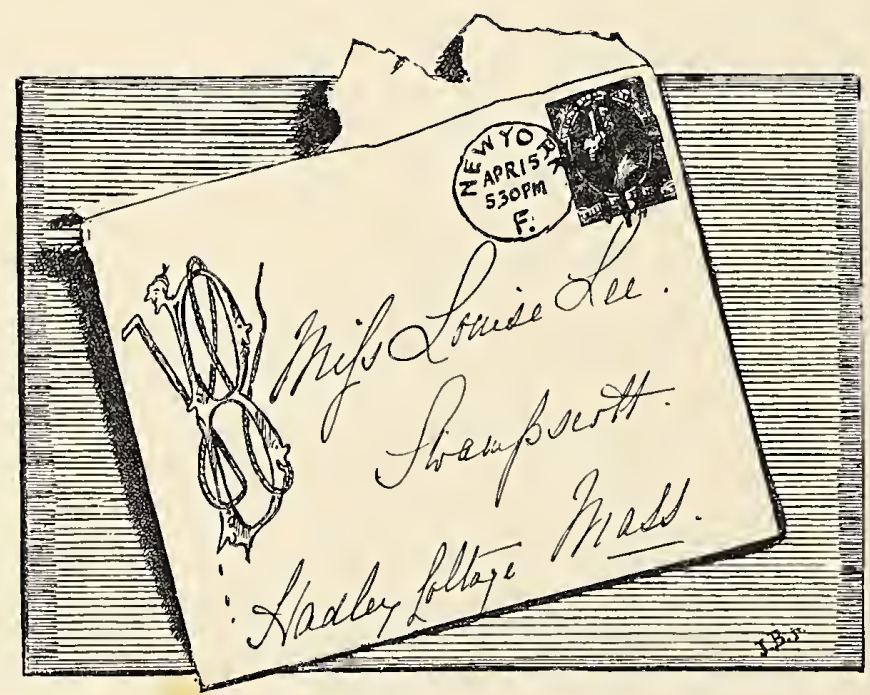




\section{Toasting Song.}

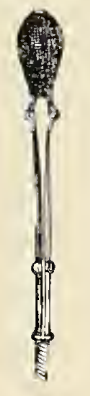

Away, dull care, away!

Till night doth bud in day,

Till dawn doth lie

In the eastern sky

With a promise bright and gay;

For Joy is king,

And his subjects sing

To the wheel forever and aye.

Away!

Uncork the wine so red

The grape of France hath bled:

Libations pour

Till our sorrows thaw, And the ice of life is dead;

Till morning steals

On our glistening wheels, And the order "Mount" is said. Uncork. 
Hurrah, my friends, hurrah!

Fast fades the morning star;

The sun doth shine

Like the red, red wine,

And our road runs smooth afar.

Let's fill one up

As a treadle cup-

To ourselves and wheels - ha! ha!

Hurrah!

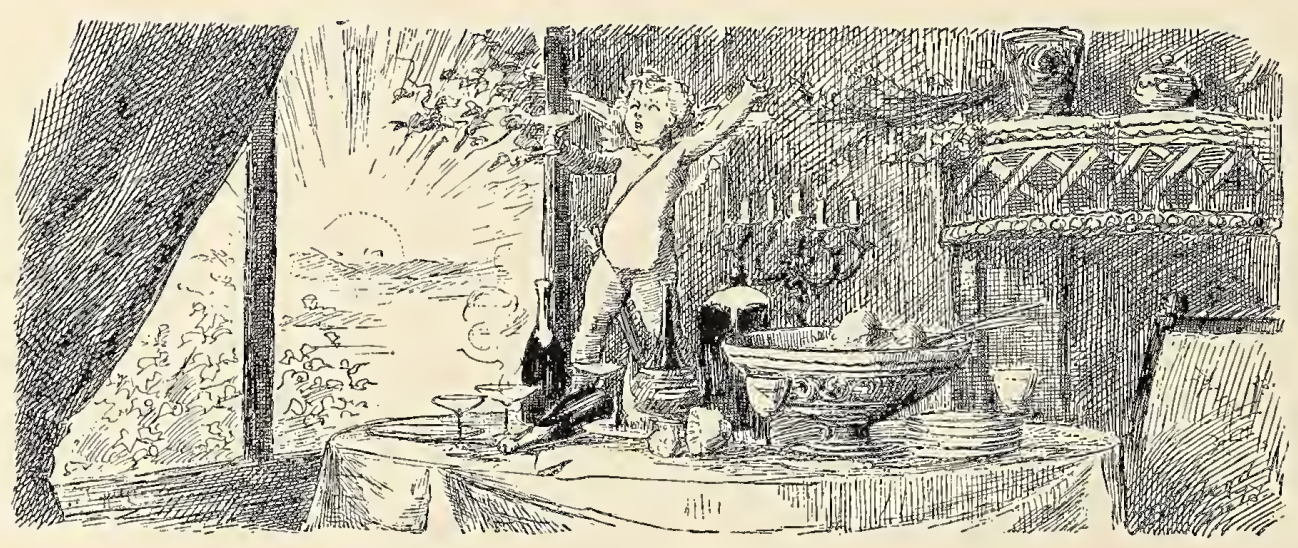



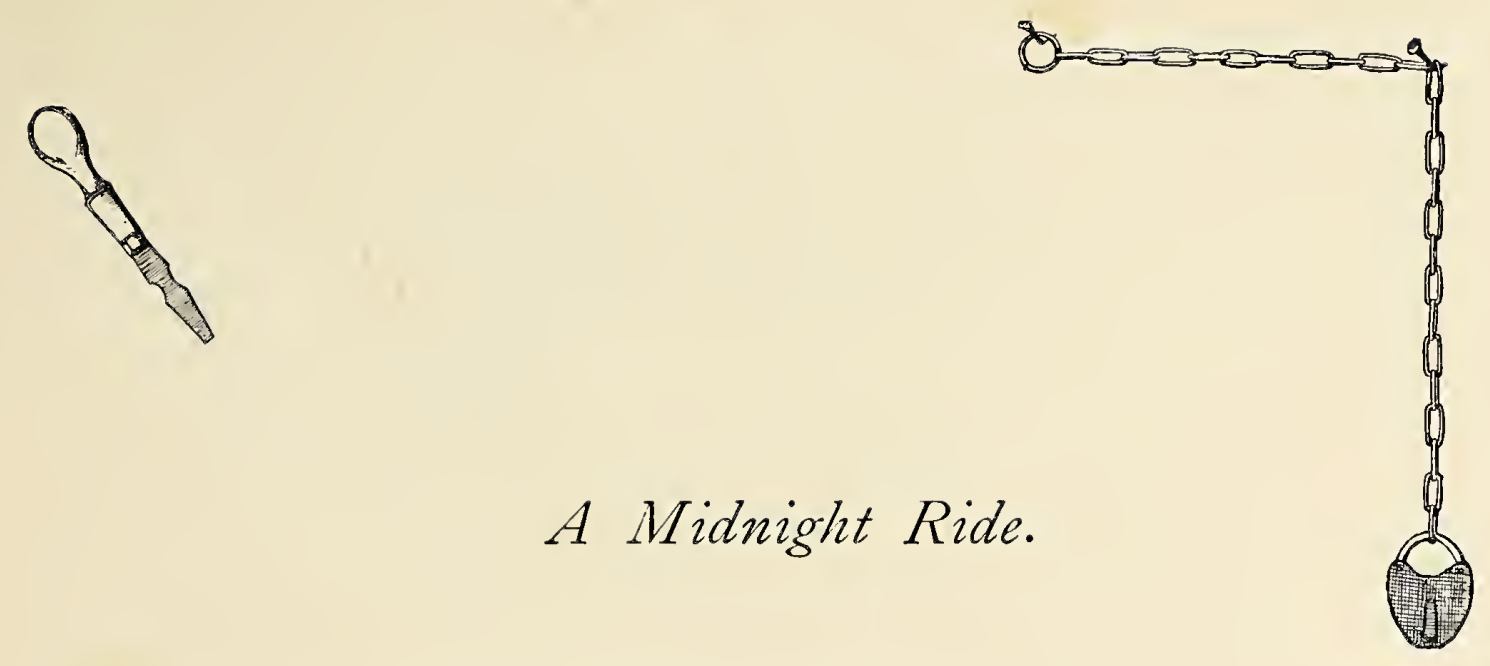

IN pretty Herter's village kirk

I did a pastor's holy work,

Yet in my breast the while did lurk

Foul treason.

With knotted cords I scourged my back.

I searched my heart, my brain did rack,

Yet for my sin could find, alack!

No reason.

My prayers I said, my sermons read,

I spoke the service o'er the dead,

Or christened babes in arms, or led

The singing;

Still, still within my breast did dwell

A clang and clangor vile as hell

Aye, louder than the chapel bell,

Kept ringing. 
"The kirk is damned, the place accursed,

Come out, O Devil, an' thou durst!

Out, out, I say, and do thy worst

In Herter."

Weird rang my challenge on the night,

It filled my coward soul with fright,

I mounted wheel, I took to flight -

Deserter!

Upon Mount Andrew's moonlit crown,

Five miles away from Herter town,

I met the Devil riding down-

I started.

"Ne'er fear, ne'er fear, ride merrily,

I'll tend thy slumbering flock," said he,

And nodding, grinning, gibing me,

We parted.

"Now as I hope for lasting grace, Thou't not usurp me of my place, Unless thou ride the greater pace!"

I shouted.

I turned my wheel, I mounted high,

I urged my steed with tautened thigh,

Resolved to in the saddle die

Ere routed. 
I saw the Devil grinning there,

My feet became a twinkling pair,

My whistling spokes cut clean the air

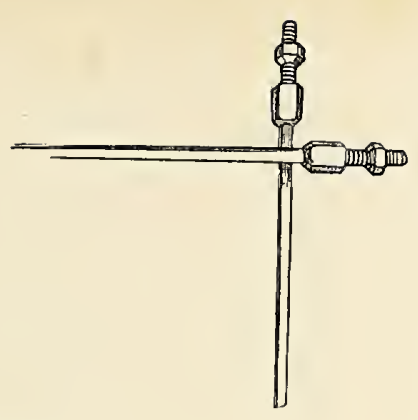

Asunder;

We darted by the mole's abode,

We startled bat and croaking toad,

The dead leaves rattled on the road

In wonder.

I saw the trees revolving by,

A whirlwind cut each straining eye, • On, on we flew, the De'il and I,

To Herter.

With heated breath and throbbing heart,

With quivering nostrils wide apart,

Along the level road did dart

To Herter.

Whene'er our path by shade was hid, My lagging pace the Devil chid, With chuckling, mocking laughter did

His cloven hoofs the treadles trod, Defy mẹ.

With every tread he gained a rod, I cried in agony: "O God,

Be nigh me!" 


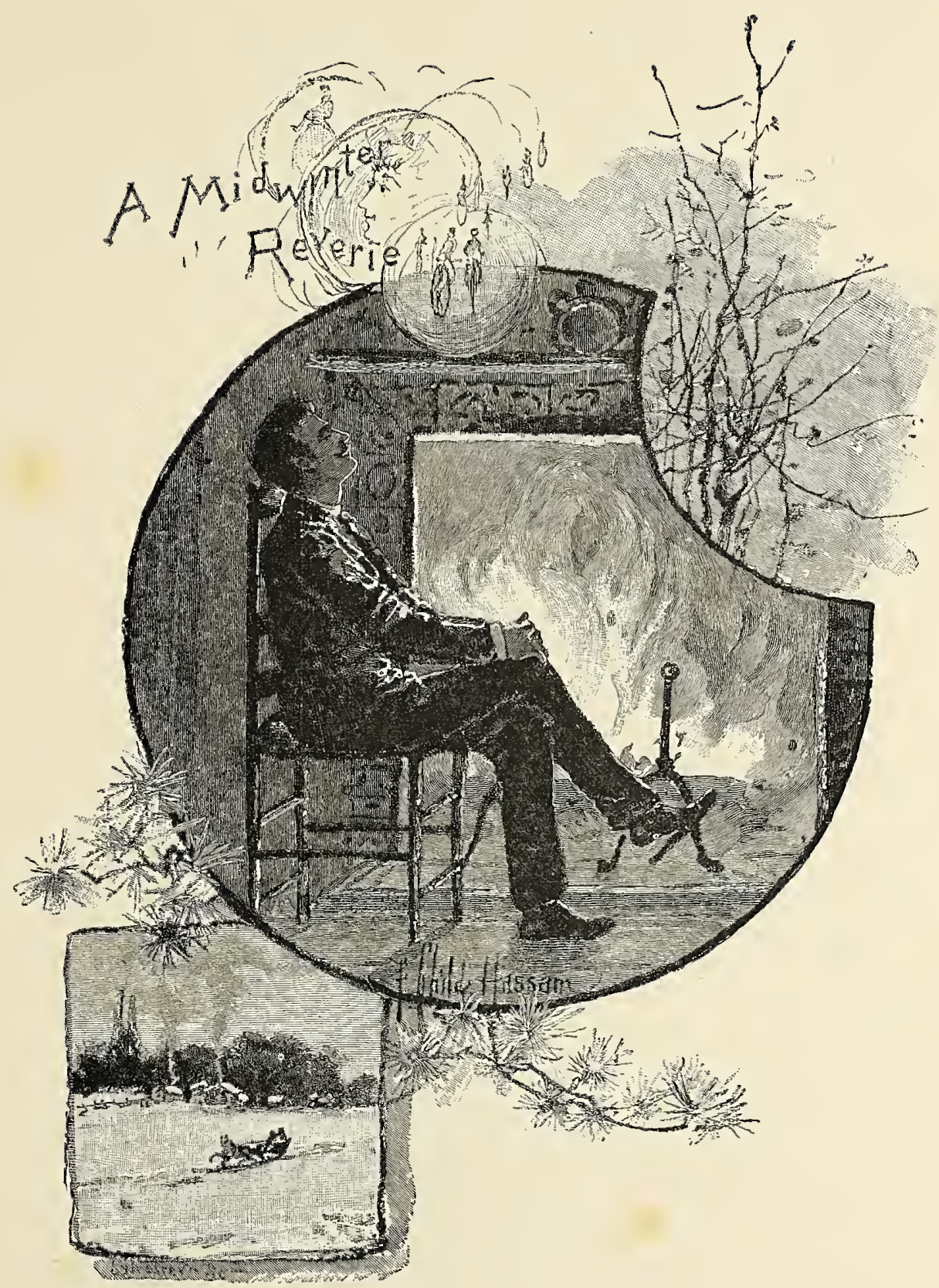




\section{A Midwinter Reverie.}

BenOLD the earth enrobed as Winter's bride,

Her snowy mantle creaks beneath the heel, While passing sleighs with merry music hide

The paths whereon we late did ply the wheel.

The frozen brook no longer gurgles by;

No more the fragrant, blooming flower is seen;

The leafless tree stands naked on the sky,

And only treasured memory is green.

No need for Milton's silent hills to speak,

Or written $\log$ to happy hours recall;

With kindling eye and pleasure-burning cheek

Full well, full well, we recollect them all. 
Those trips a-wheel before the break of day,

The pause to hear the morning songsters sing, The break of fast on berries by the way,

The thirst assuaged by kneeling to the spring;

The drill, the race, that memorable run,

Quixotic like, in search of conquests fair, -

Each 'joyed event returns like Summer sun,

To warm the chillness of the Winter air.

Roll on, ye frosts, and spend your rime and hoar!

O despot Winter, sway your substance through!

Full soon the hour when Summer reigns once more,

And we enjoy her ecstasies anew.
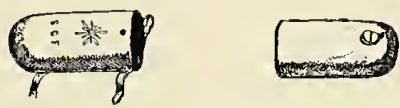


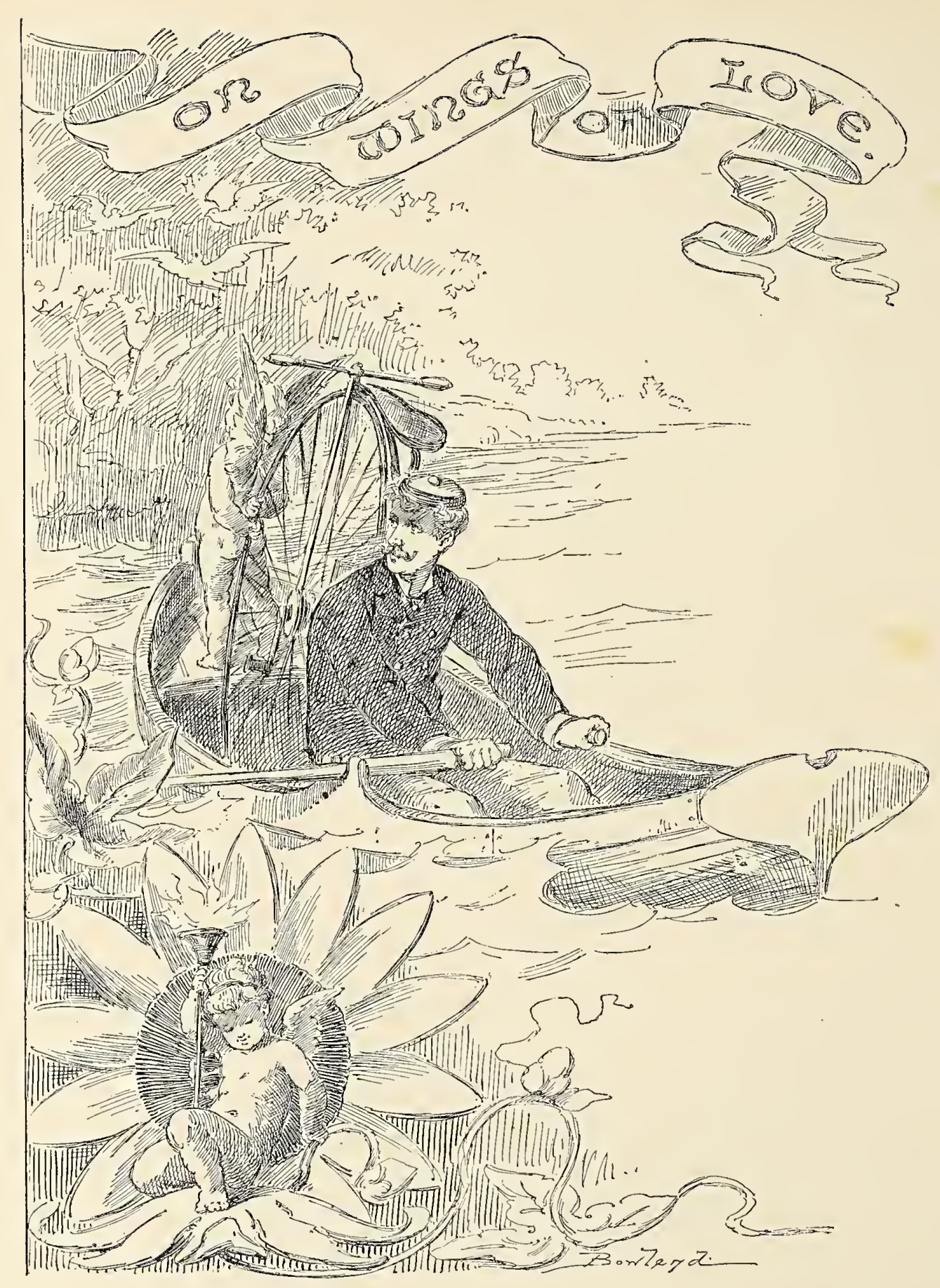




\section{On Wings of Love.}

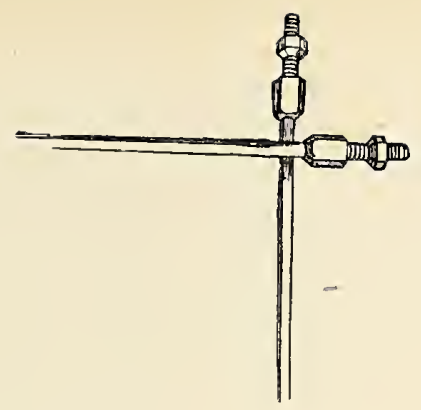

FRESHETS rushing,

Bridges crushing,

Stay the way of

Train and team-

What bold stranger

Braves the danger?

Who doth cross yon

Angry stream?

Strongly, swiftly,

Deeply, deftly,

Dip his paddles

In the tide;

Bravely done, sir!

Nobly won, sir!

See! he gains the

Other side.

Wheel he carries,

Waits nor tarries,

Mounts, and quickly

Rolls away;

While in wheeling,

Joyous feeling

Vents in happy

Roundelay. 


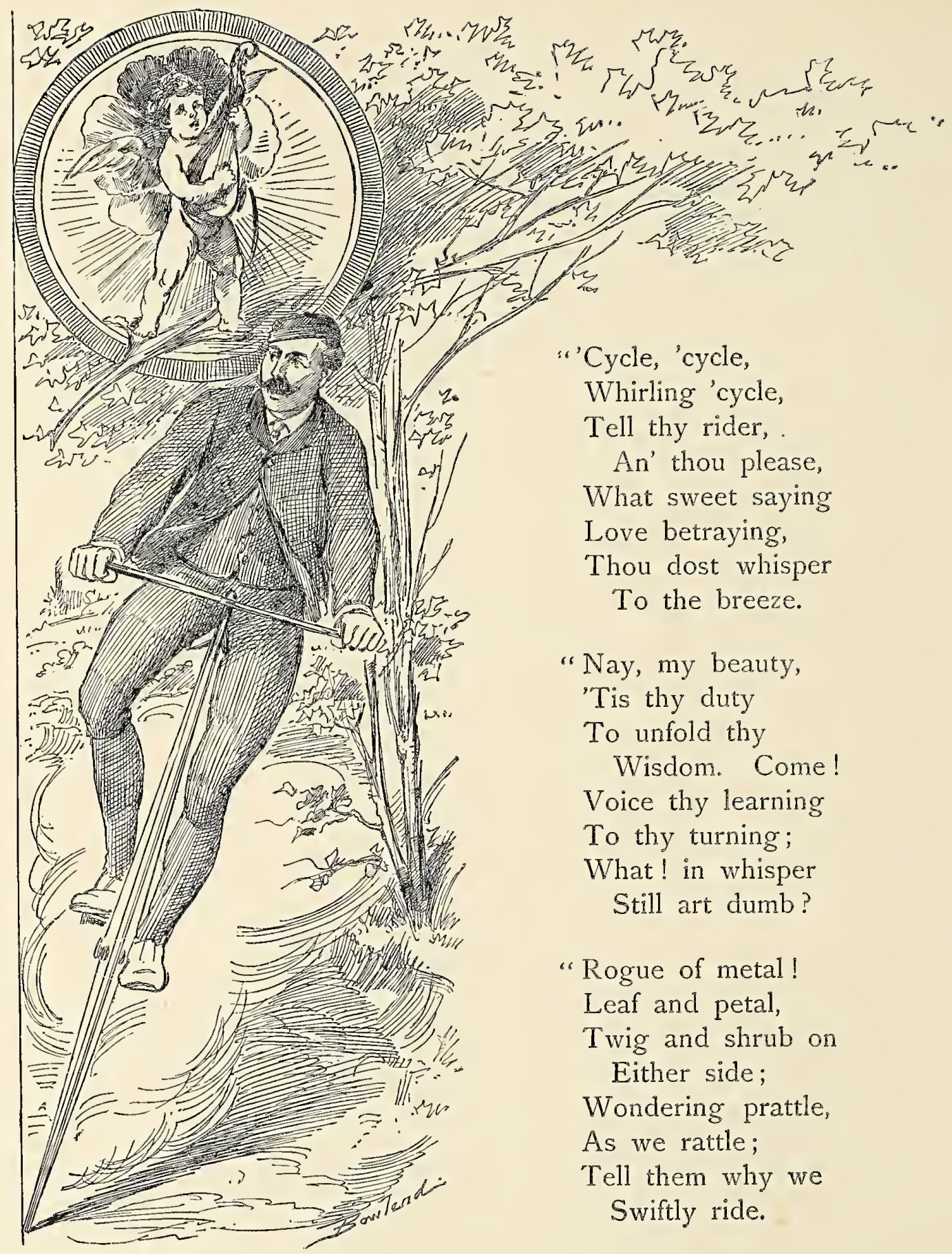




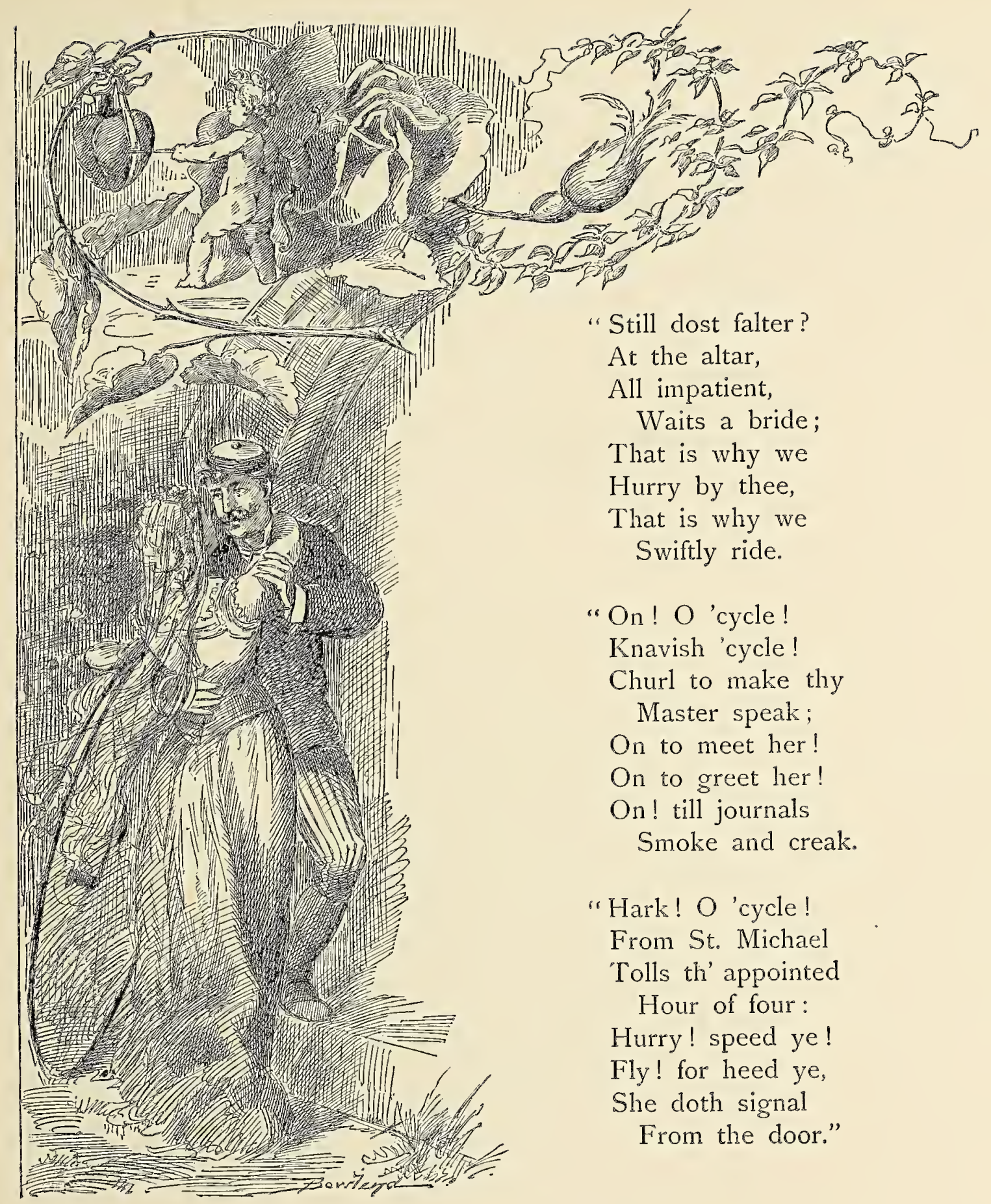




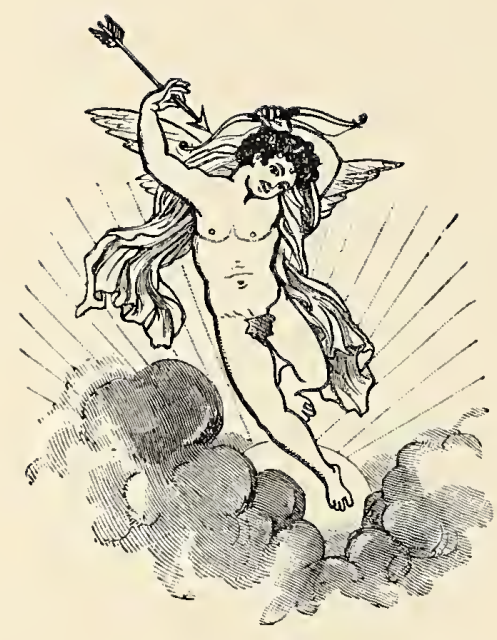

Wheel Bliss.

Every morning as I spin

On my wheel for exercise,

Such a pretty glance I win

From a pair of pretty eyes,-

From a maiden full of mirth,

Bearing on her curly head

Jug of milk, a penny-worth,

And a two-pence-worth of bread. 
Poor the lassie is, I know,

Yet contented with her lot:

In her tidy calico,

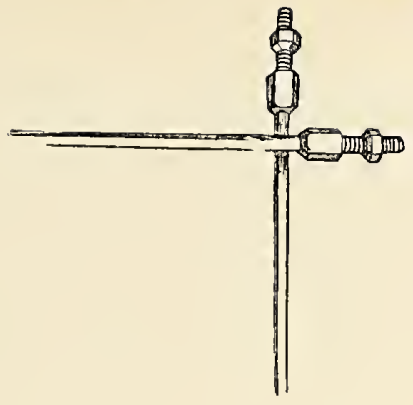

As she saunters to her cot,

She is queen of all the earth,

And the crown upon her head

Is the milk, a penny-worth,

And the two-pence-worth of bread.

Maiden, will you marry me?

O'er the rugged road of life

I could wheel right merrily

With so sweet a little wife;

Do! I'll dress you up in silk,

And I'll go myself, instead,

For the penny-worth of milk,

And the two-pence-worth of bread. 
Every morning as I ride -

Ah, what blessed paradise!

Nestling closely to my side

Sits my wife with pretty eyes;

Laughing, talking, full of mirth,

As we swiftly forge ahead

For the milk, a two-pence-worth,

And a four-pence-worth of bread.

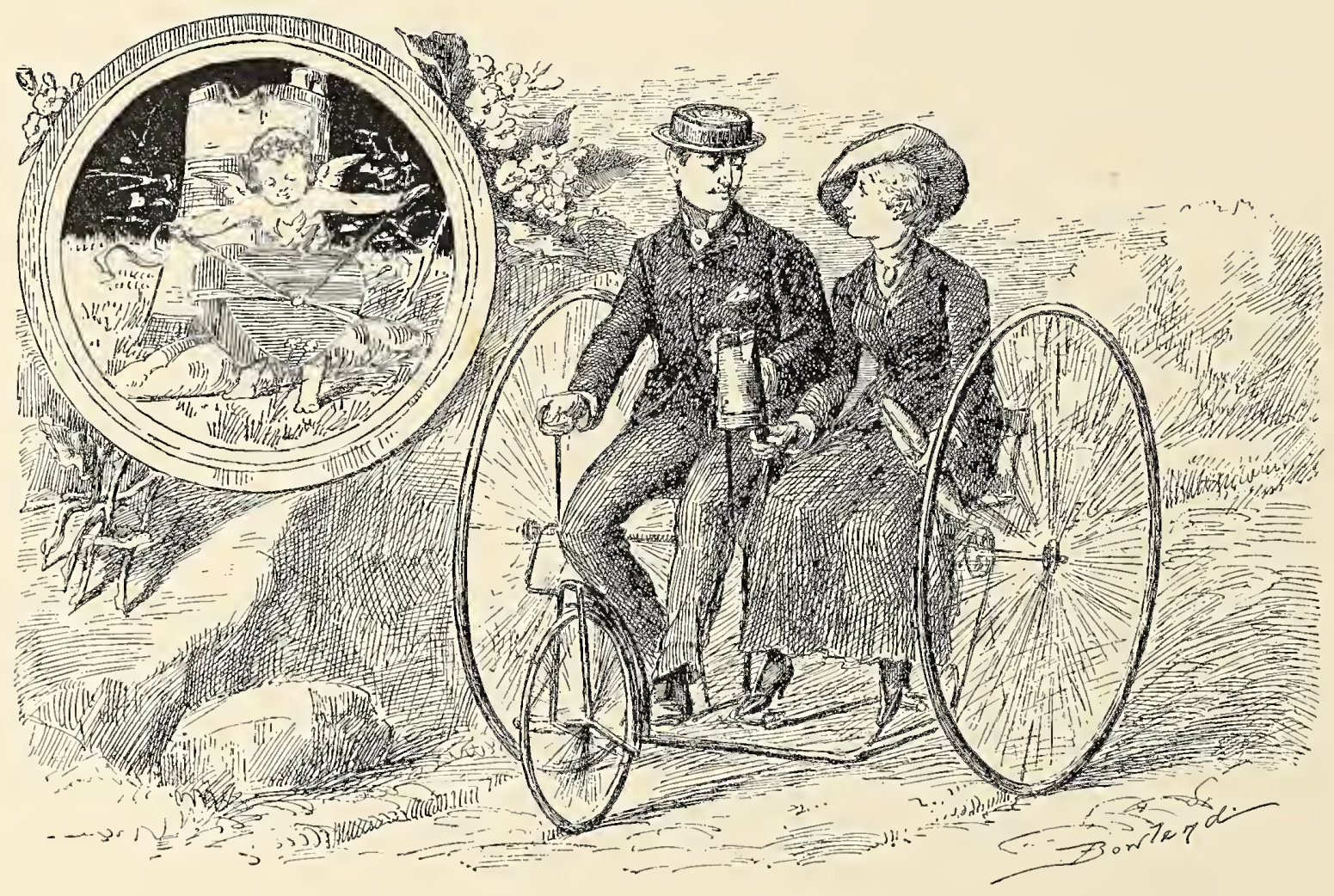




\section{In Memoriam.}

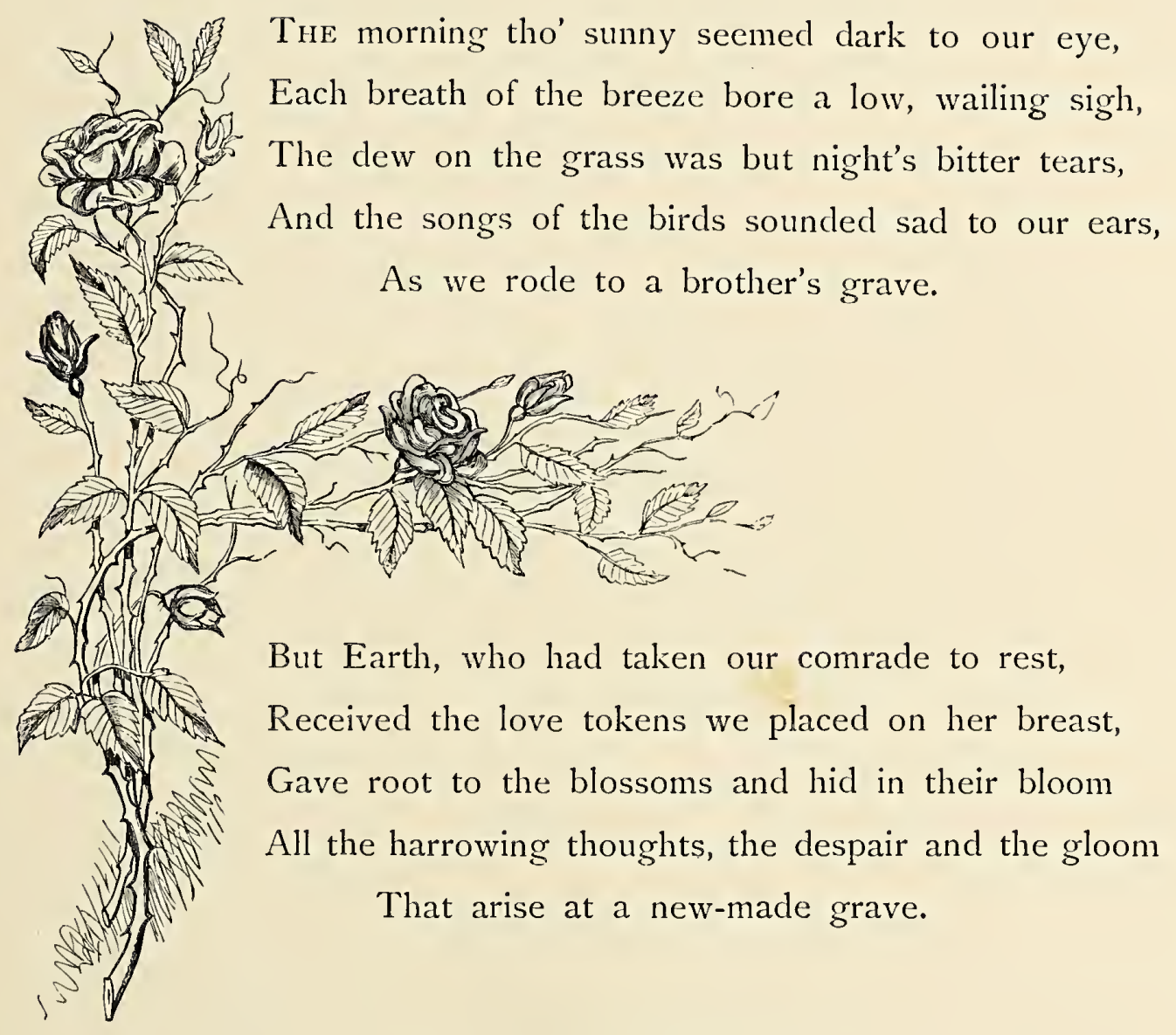


The mound that betokens the fell work of Death,

Is lost in the scent of the roses' sweet breath,

No longer we shudder, no longer we mourn,

But all calmly remember the one who is gone

To his sleep in a rose-strewn grave.

[The first sad event in the history of the club was the death, on the $5^{\text {th }}$ of September, 1880 , of a valued member and a promising young journalist - Edward Hogan. He was buried in a pleasant rural cemetery in Waltham; and on a following Sunday the members of the club, in usual costume, except that they wore a little folded crape under the silver star, met and mounted wheels by Trinity Church, and rode two by two, each carrying a bouquet of flowers for his grave, to the gate of the cemetery. Dismounting there, they took their silent march to his last resting-place, left the flowers, and returned as they went. A few words from the president to the bereaved family, who happened to be present, were said, and nothing more.-Charles E. PRATT's "History of the Boston Club."]

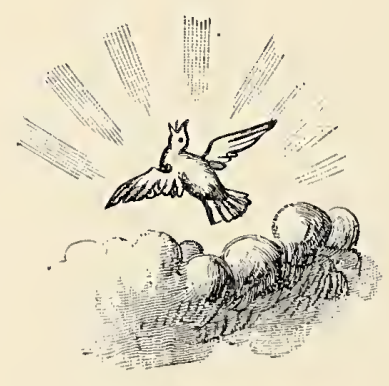




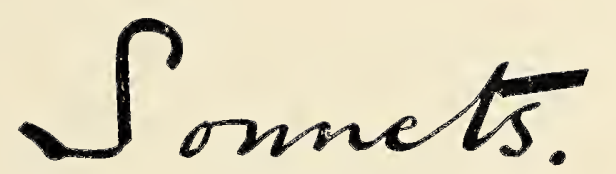

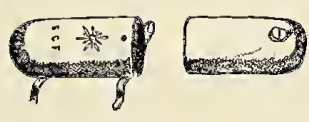





\section{To C. E. P.}

I WISH one more proficient in the art

Would touch the poet's harp and sing your praise,

That I, in hearing his more perfect lays,

Might find in their expression what my heart

Would say, but, lacking skill, can ne'er impart.

View, then, my simple words as but the rays

Of friendship's sun concealed, the which to gaze

Upon would blind, as tho' Sol's counterpart,

So brightly does it shine for you whose pen

Has dropped such ornaments for wheeling men;

Whose pleasant leadership and genial look

Have, like the ever-spreading Banyan tree,

Sent forth the branches of your worth, thro' nook

And corner of our whole fraternity. 


\section{To My Bicycle.}

FAR swifter than e'er Atalanta flew,

And silent as the working of the mind

Thou glidest, leaving city walls behind

To fly to where - in many a brilliant hue

Beneath the moon's pale light - the sparkling dew

In trembling, scintillating drops is found;

Where odors sweet and fragrant fields abound

And nature breathes to man of life anew.

Amazed, I guide thee, noiseless thing of steel!

Scarce using force to urge thee thro' the night,

Wondering if thou, like me, dost bondage feel,

And find relief in this green-pastured flight;

If thro' thy frame the travelled pleasures reel

Responsive, haply, to mine own delight. 


\section{To the New Year.}

BY A BICYCLER.

All hail, $O$ first of Jan.! thou greatest day

(For swearing off) of all the merry year;

When whiskey topers drop to lager bier,

And beardless youths demand a "raise" in pay.

When thou appearest in thy slushed array,

Thou bringest us a thousand trophies dear,

The barber boy's insinuating leer,

The postman's blithe, explanatory lay;

For these, and more, we thank thee; but, O Jan.,

The wheelman's benison will never flow

In praise of one who steals his summer tan,

And blocks the boulevard with ice and snow.

If thou wouldst note the cycler's happy eye,

Retain thine icy gifts till - well - July.

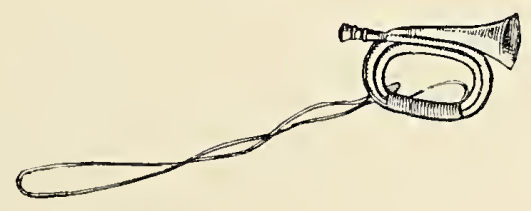





$$
\text { ○ }
$$





\section{Si. Plunkitt.}

AT farmer Plunkitt's well I stop,

The bucket's rim to kiss;

As down my throat the waters drop,

Down trickles, also, this;-

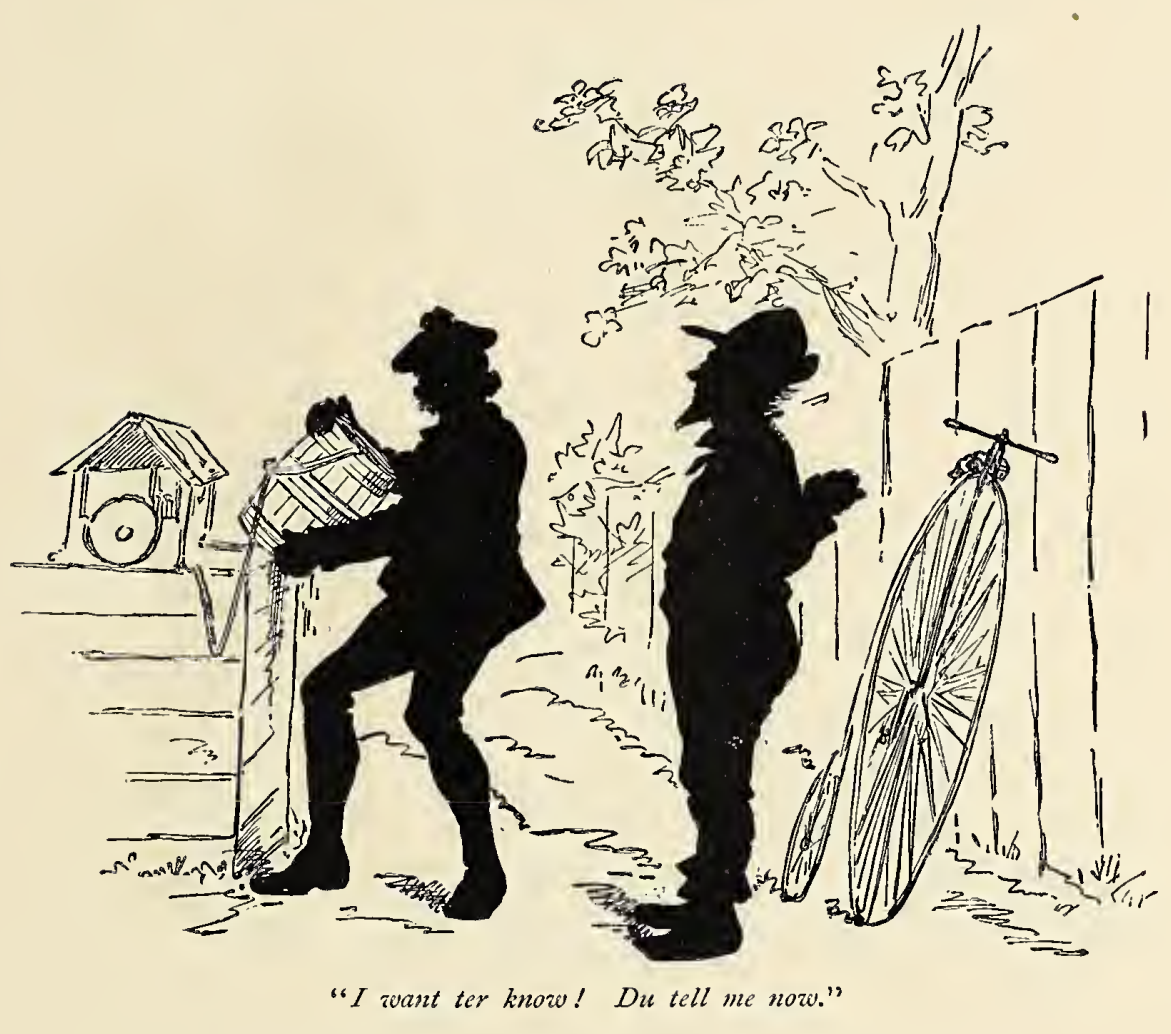

"I want ter know! Du tell me now, $\mathrm{Yu}$ ben't thet feller, be yer,

$\mathrm{Az}$ puts them rhymes in print? I vow!

I'm plaguey glad tu see yer. 
"I yused ter pen fur papers tu

When I waz 'bout so big;

But now I haz tu much ter du

A pennin' fur thur pig.

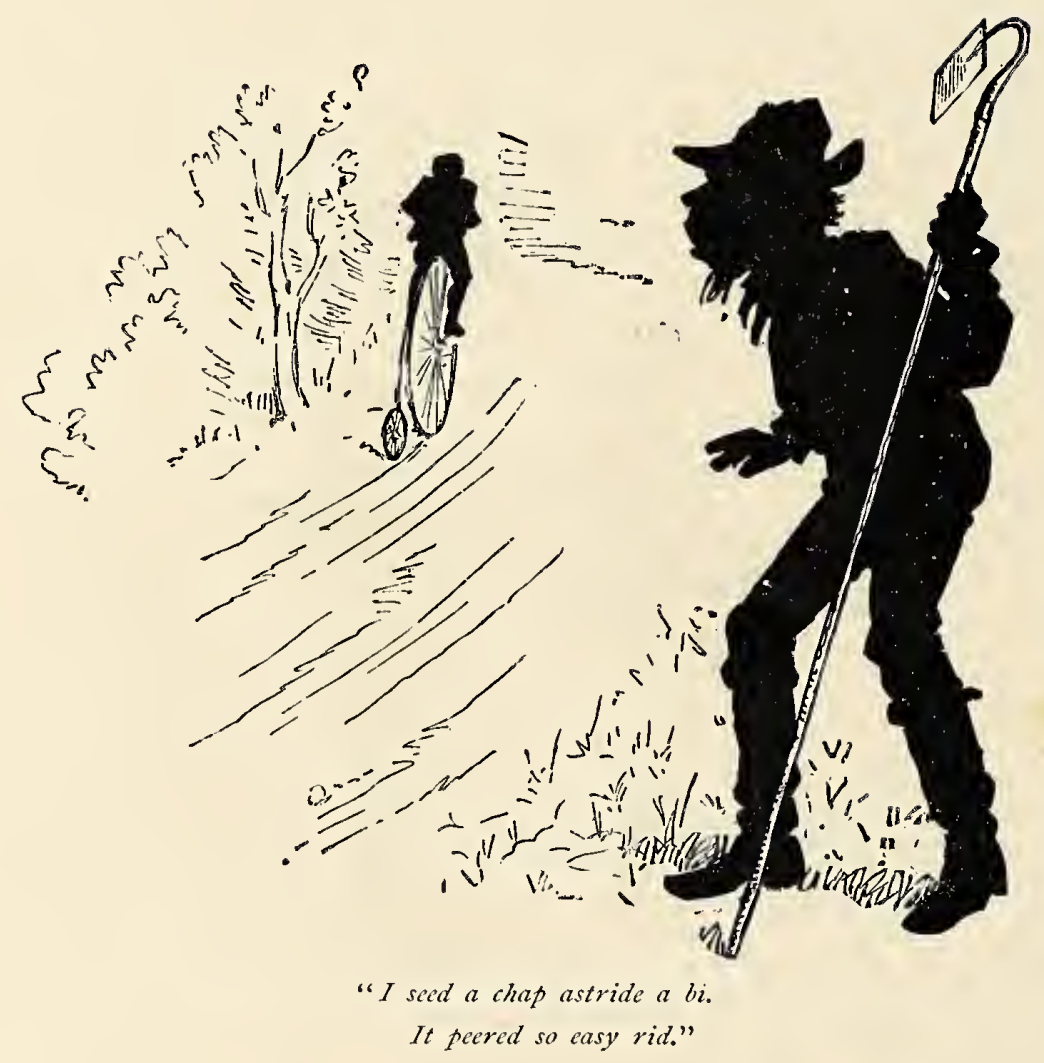

"Them things be eazy rode. Oh, yes,

I yused one time tu spin 'em;

Enjide thur sport sum, tu, till Bess

She sot hur foot ag'in 'em. 
"I seed a chap astride a bi., It peered so eazy rid -

'Si. Plunkitt, buy a bi.,' sez I; An' by an' by I did.'

“' What's thet?' sez Betz. 'A hoss,' sez I, 'Gee-hossy-phat!' sez Betz, $A z$ up I fly a fathum high, An' thru a hot-bed sets.

“" Thet there's a hoss,' sez Betz tu me, 'Az ort tu jine a surcus;'

'Lor, Betz,' sez I, 'how green yu be! I did that thar a-purpus.'

"I mounts ag'in. 'Shet up yer jaw!' Sez I, az down I slid; Sez Betz, 'I didn't speak;' 'Oh, pshaw! I thought,' sez I, 'yer did.' 
“I took mi boots an' westkit off With great deturminashun,

An' up I gets - Betz gave a korf

$A n^{\prime}$ balked mi kalkulashun.

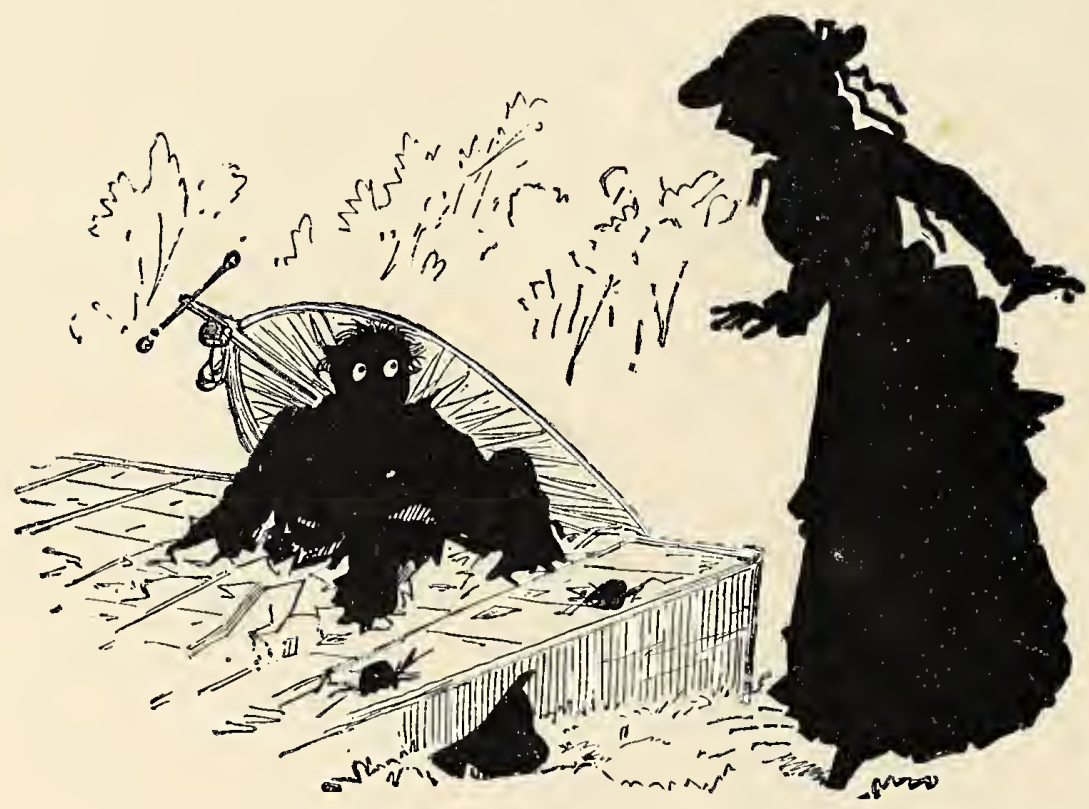

“'Lor, Betz,' sez I, 'hozv green yue be! $I$ did that thar a-purpus."

"I shooted down thur hen'ry stair, Clean thru a winder shot,

I pawed thru air, I sawed thru air, An' sored miself a lot. 
“" See what yer done!' I yelled, mi hed An' ev'ry jint a-akin',

'Thet tarnal korf o' yourn,' I sed, 'Kum nigh mi koffin' makin.'

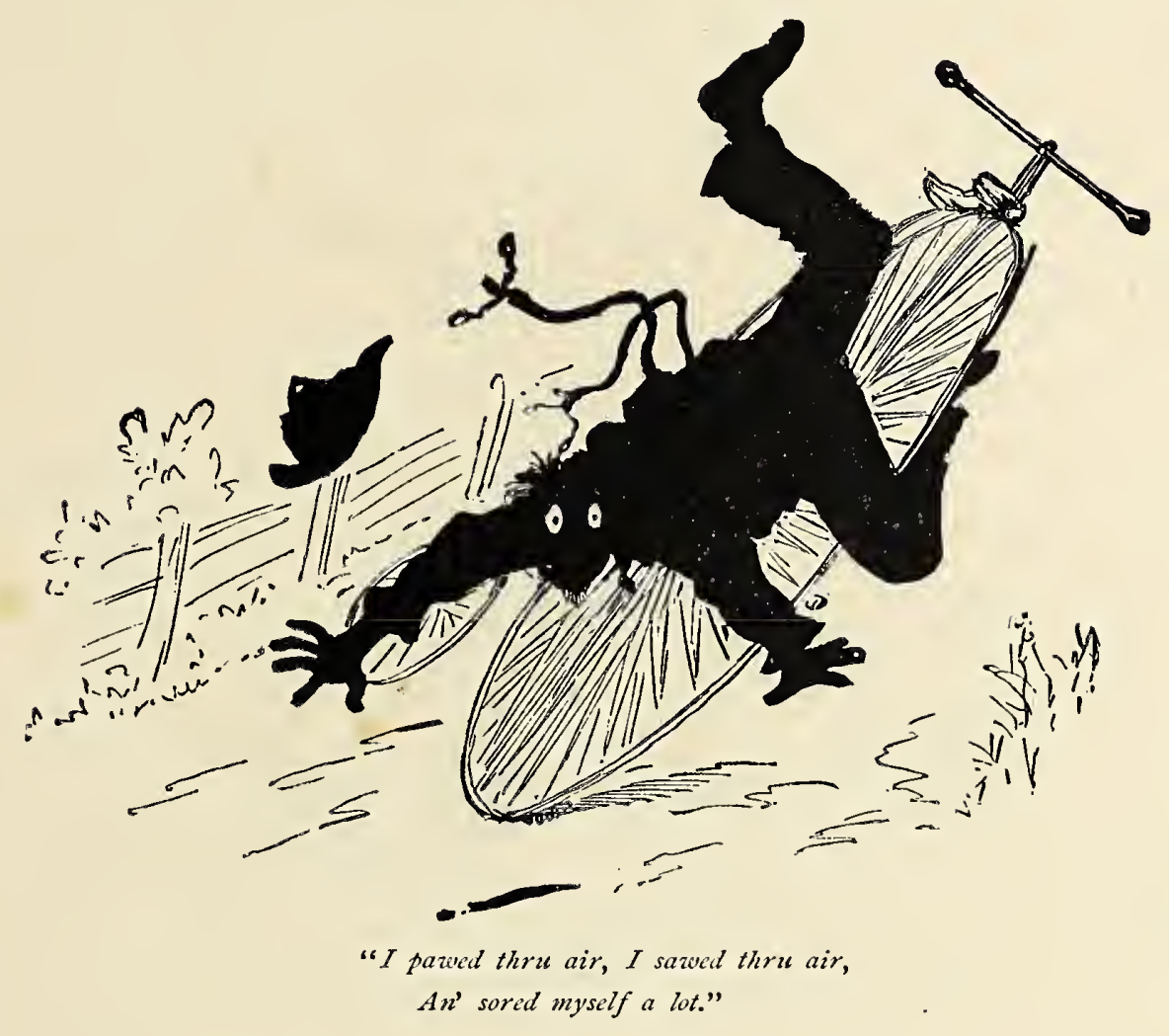

"Sez she, 'Jest let me hold it, Si.,'

I looked Betz Plunkitt thro';

She'd balked mi game so orfun I

Waz sumwat skeery tu. 
"“Wal, hold,' sez I; 'Set straight,' sez she;

'Shet up, yu'll balk!' I hollered;

Tu late - hur knee was driv in me,

An' haf hur hoof I swallered.

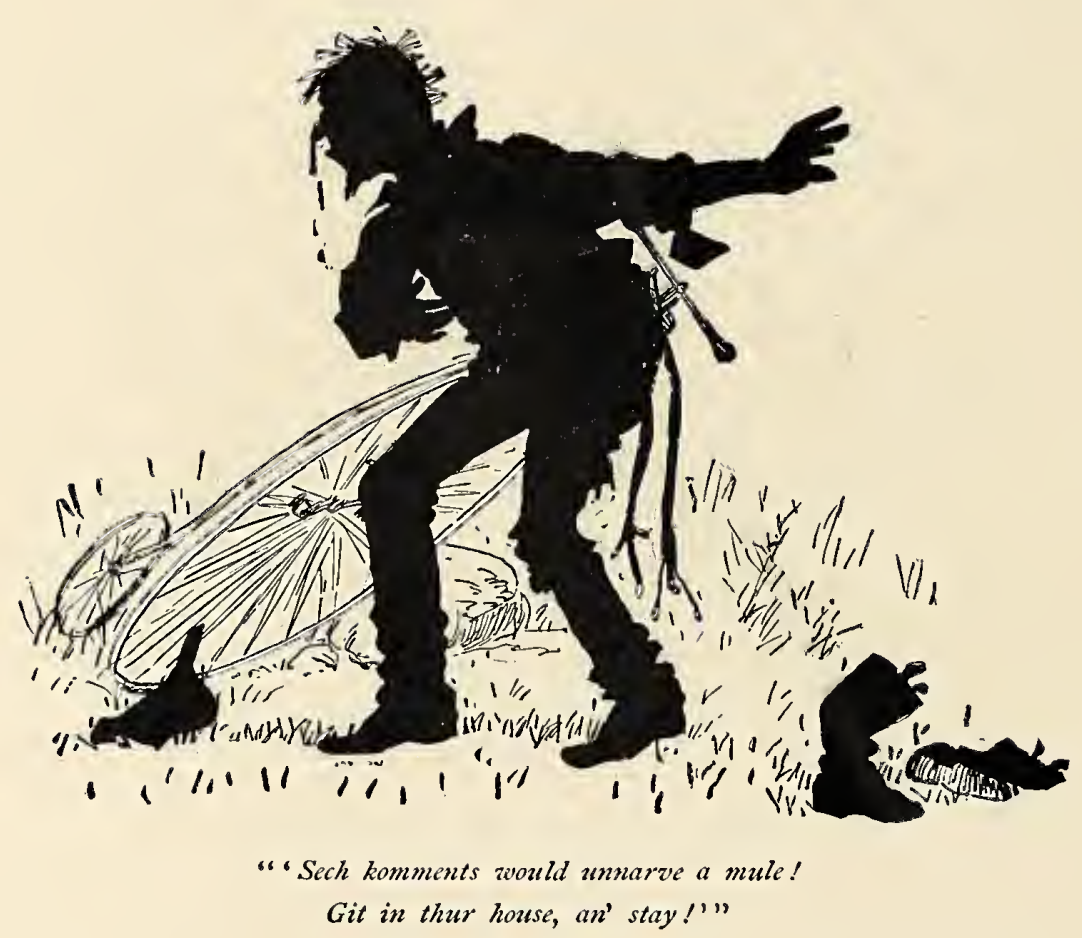

“'Gol-ri!' sez I (quite kalm an' kool),

'Cl'ar out! yer in thur way!

Sech komments would unnarve a mule!

Git in thur house, an' stay!' 
"I slacked mi spenders, chucked mi tie An' koller on thur grass -

'Thur sty I'll fetch this time,' sez I, 'Or style miself an ass.'

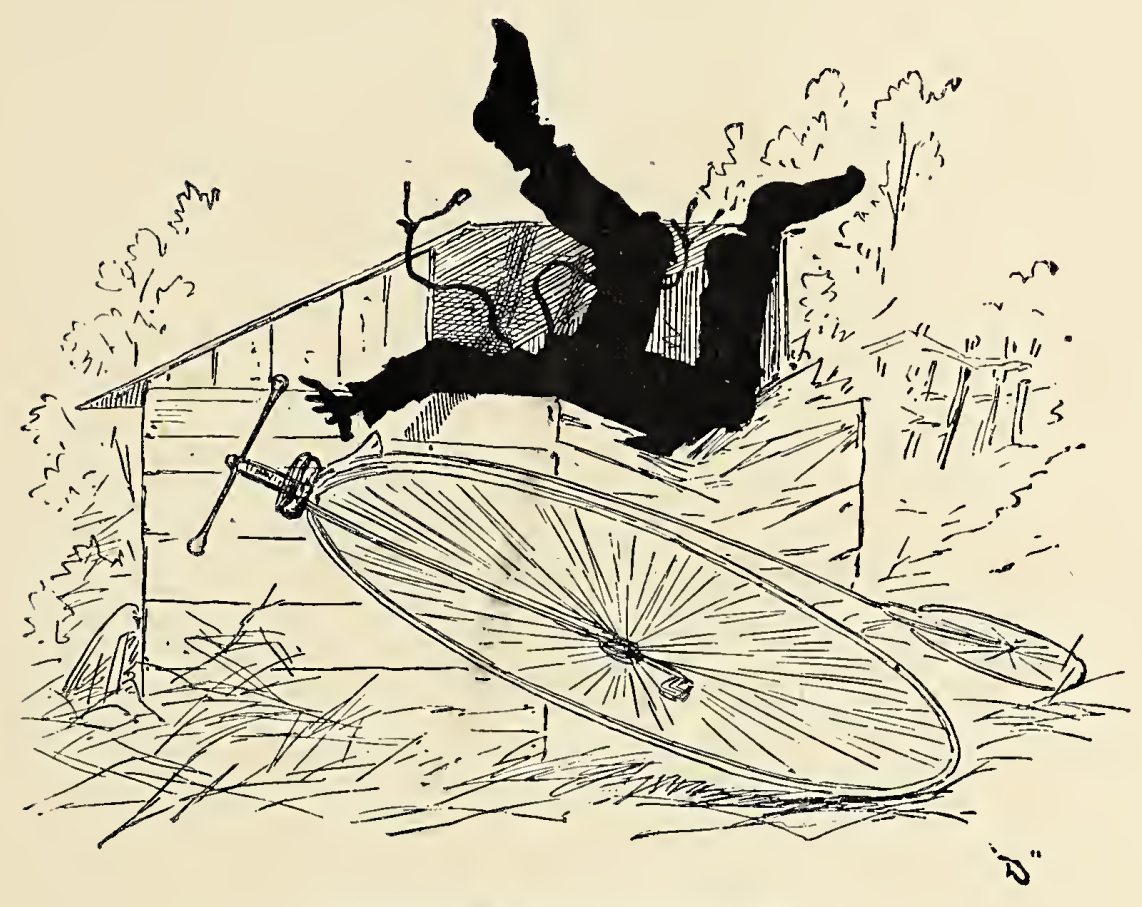

"I fetched thur sty-inside - kerslam!"

"I fetched thur sty - inside-kerslam!

Az sure az I'm Si. Plunkitt;

Kum mighty nigh a sayin' damn,

So pesky loud I thunk it. 
"I riz. Betz on thur pyazzy stood.

'I'll quit,' sez I, 'this minnit -

I'll quit it, Betz,' sez I, 'fur good,

$\mathrm{Az}$ yu're so sot ag'in it.'

"Oh, yes, them things be eazy rid,

Ter mount, glide on thur seat;

Stop gradyerly, thur way I did,

An' lite upon yer feet."

The music of his nasal twang

No longer rhythmic flows;

No more his verdant breath doth hang

About my weary nose.

I say farewell, I gain the road, Faint follows as I spin it;-

"Thet's jest thur graceful way I glode,

Till Betz got sot ag'in it." 


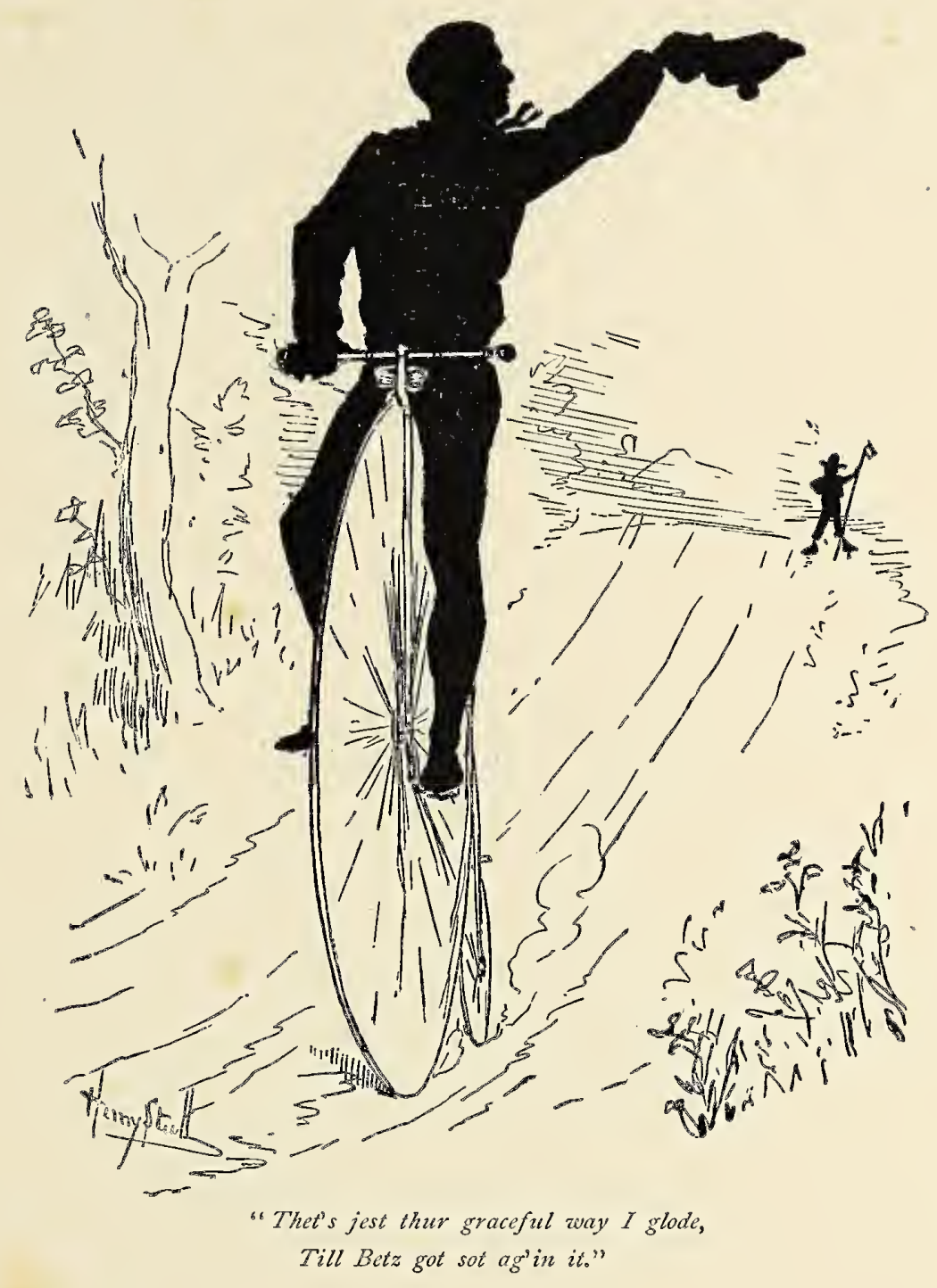




\section{Eldorado.}

A tale of the Central Park, After E. A. POE.

GaYLY bedight,

A cycling knight,

With cheek and loud bravado,

When it was dark,

Hied to the Park

In search of Eldorado.

The hour was late,

He passed the gate

In the night's concealing shadow,

And there he found

Some hunky ground,

Which looked like Eldorado. 
But all his strength

Failed him at length;

He met a peeler's shadow;

"Shadow," said he,

Innocently,

"Please, where is Eldorado?"

A duplex rap

On the cycler's cap,

Gave the cop's substantial shadow;

Declined his tin,

And took him in

To the land of Eldorado. (?)

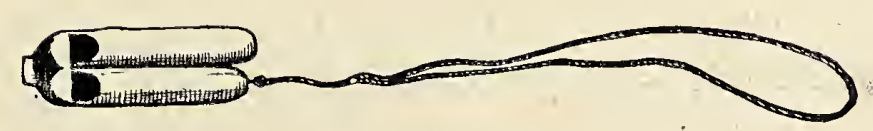




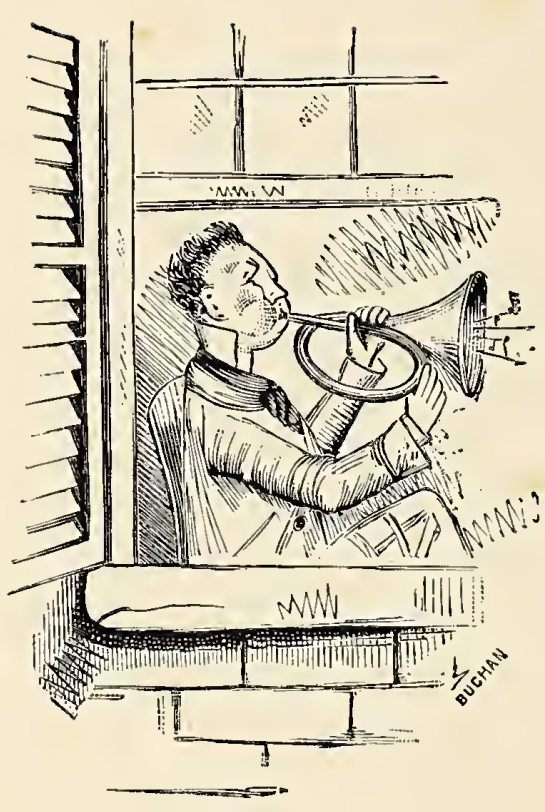

\section{That Bicycle Bugle.}

\section{AIR-_"The Old Oaken Bucket."}

How near to my ear are the notes of that trumpet!

They float on the breeze with the dawn's early light;

I swallow them down with my Sunday tea crumpet,

And dream of their din in the dead of the night.

How often when trying some rhythmic inditing,

When just at the door of my subject I knock,

There comes thro' the window - upsetting - affrighting -

The screech of the bugle that toots on our block.

That bicycle bugle - that six-dollar bugle -

That double-decked bugle that toots on our block. 
I've stood the street organ, the fifer and drummer,

But standing this bugle is no sort of fun;

If 'tweren't so expensive I'd charter a plumber,

And solder a trap in its last curve but one.

When blown by its owner- some raw ignoramus -

It ties up my nerves like a galvanic shock;

I'd rather have cerebro-spinal-jim-ja-mus,

Than list to the bugle that toots on our block.

That falsetto bugle - that wind-spavined bugle -

That calf-braying bugle that toots on our block.

There's work for the League in this brazen formation;

Suppress it in toto; or shorten its scope

By raising the rate on its vile importation;

Consider the matter - do, please, Colonel Pope.

I think of the fellows, with rapt admiration,

Who threw the tea overboard into the dock,

And wish they were living in this generation

To chuck in the bugler who toots on our block.

That mongrel-mouthed bugler - that overgrown bugler -

That limber-lunged bugler that toots on our block. 


\section{Mister Tobias Isaias Elias.}

HE was dressed in a beautiful corduroy suit, With a whistle to blow and a bugle to toot, With a bicycle book and a map of his route, And a lamp and a multum-in-parro to boot.

Chorus.-Mister Tobias Isaias Elias

Went out on the bi. and returned on the bias;

Now, if Mister Tobias Isaias Elias

Went out on the bi. and returned on the bias,

Where is the bi.?

Also Tobi.?

Where is Eli-Eli-Elias?

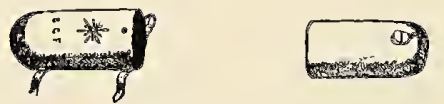


As he mounted his steed of invincible steel,

His delight he endeavored in vain to conceal,

So he placed on the end of each handle a heel,

And described a few didoes on top of his wheel.

Yes, he swerved and he swooped with the grace of a hawk,

And he smiled and he smirked at the maids on the walk,

When - I'm blest if his blasted old bi. didn't balk,

And Tobias shot hastily over the fork.

Now the coroner's jury will tell you the rest, If enough of his body be left for the 'quest, For the people who witnessed the header attest, That he scattered himself from the East to the West.

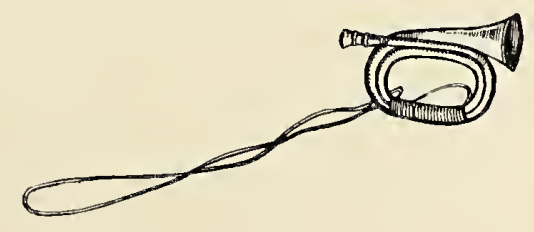




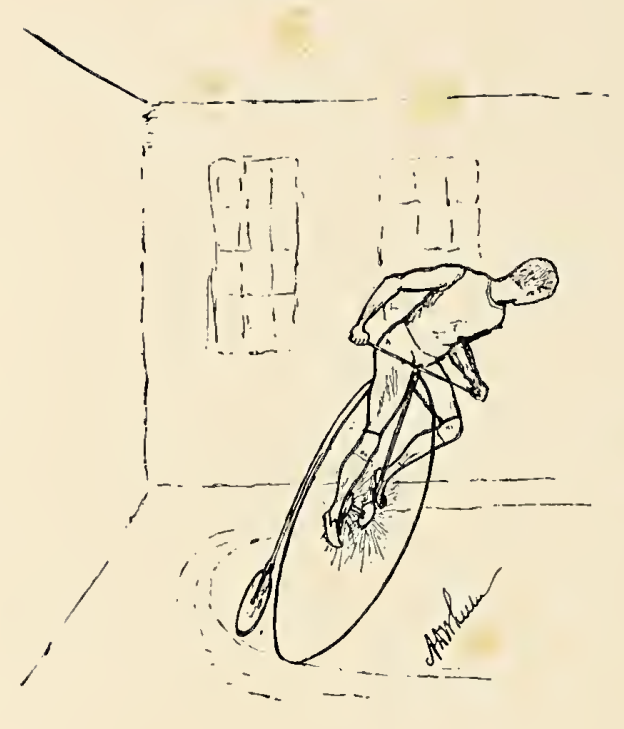

\section{Training for the Race.}

Whew! Did ye hever see henny-think like it, the way 'e's a flyin' round?

What do ye s'pose the younker ud do with a track for 'is trainin'-ground?

I tell ye, Bob, 'e's as likely a covey as hever I 'ad in tow;

The feller what shows 'im 'is little wheel ye 'ad better believe haint slow. 
What! ahead o' the record a minute! an' still 'e's a spinnin' round!

If 'e puts that on to-morrow, mate, we be winners a 'undred pound.

Just keep this performance shady, Bob, an' we'll divy, will you an' me-

The manner'e dives at that nasty curve just a curdles my blood to see!

Slow hup! slow hup, my hindustrious kid! ye be hover a-steppin' work.

Slow hup! an' I'll give ye a rubbin' down as is fit for a royal Turk.

Yer a-doin' a-middlin' well, my boy, but yer time is a trifle bad;

Just a leetle be'ind the fence, ay, Bob, just a leetle be'ind, my lad.
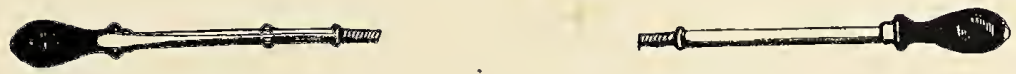
Truo Stable Remarks.

He bridled up - in horsey tones

Whipped out this bit-ter shaft:

"He who on cycle tires his bones

Is cranky, weak, and daft."

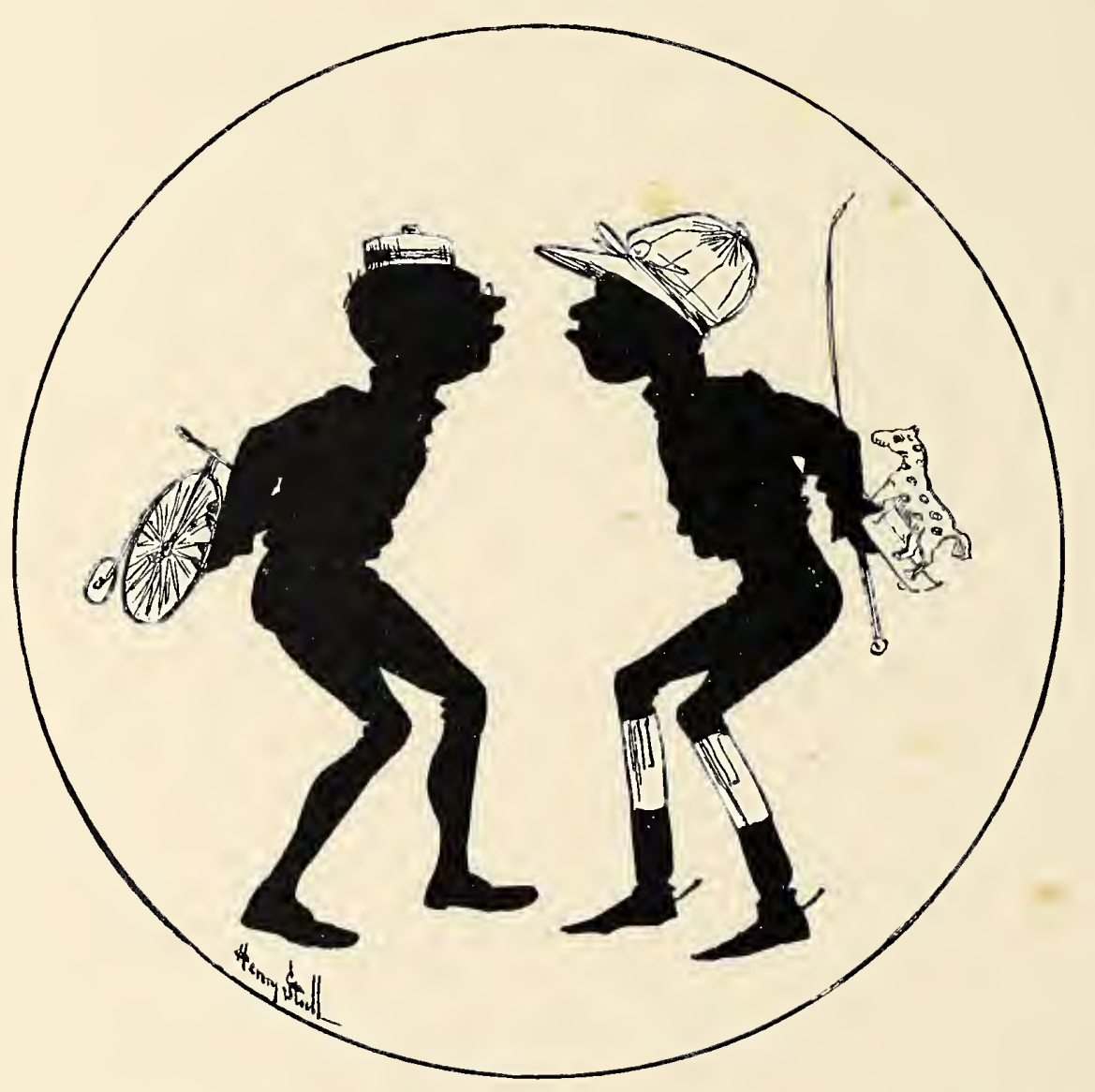

"A trace of choler, sir, you show," -

Thus spoke the man of steel;

"Your sulky life is full of whoa,

My cranky one of wheel." 


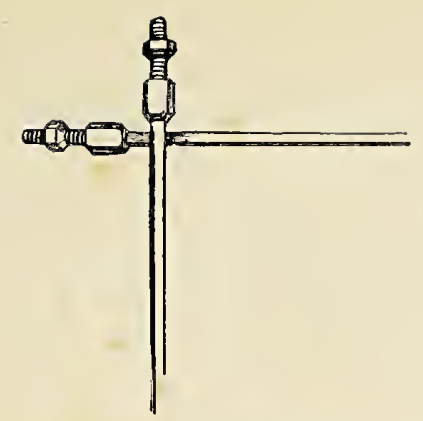

\section{The Boycycle.}

AN' fare 'ave yer bin to? An' phat is it, Terrence?

A boycycle is it! An' phat is it for?

To roide on ashtraddle! go lang wid yer, Terrence, Yer'd break ivery bone in yer back on thur floor.

Now don't yer be thryin' yer thricks wid yer mother;

An' phy wan't ye home to yer supper before?

An' me wid thur babby, an' only yer brother

To draw all thur wather an' wait on thur sthore.

An' phat is that thing hanging there in thur middle?

A lanthern! faix, hang it up over thur door!

'Twill loight up thur notice as foine as a fiddle:

"Here's Mrs. O'Flaherty's Grocery Sthore." 
Yer hans are that filthy, an' black beyont menshun; $\mathrm{An}^{\prime}$ how did it come as your breeches wuz tore? The boycycle did it! thur divil's invention! I'll not have yer roidin' thur thing anny more.

Get down from there, Terrence! come back yer young villin!

Och, mother av Moses! an' ain't there no law

To punish a poor widdy's son, as ain't willin'

To sthop wid his mother, an' wait on thur sthore?

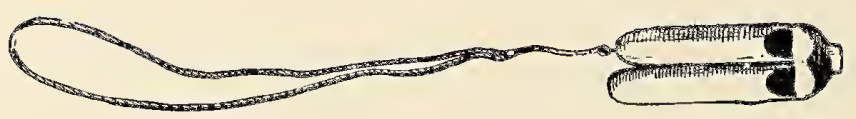




\section{Loose}

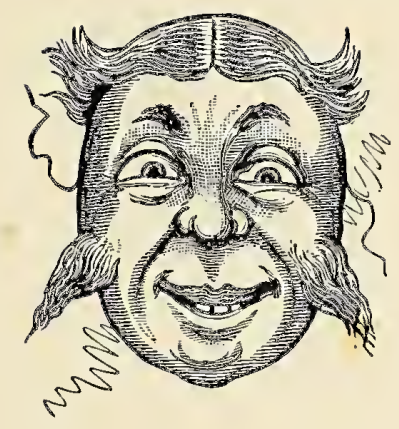

Spokes. 



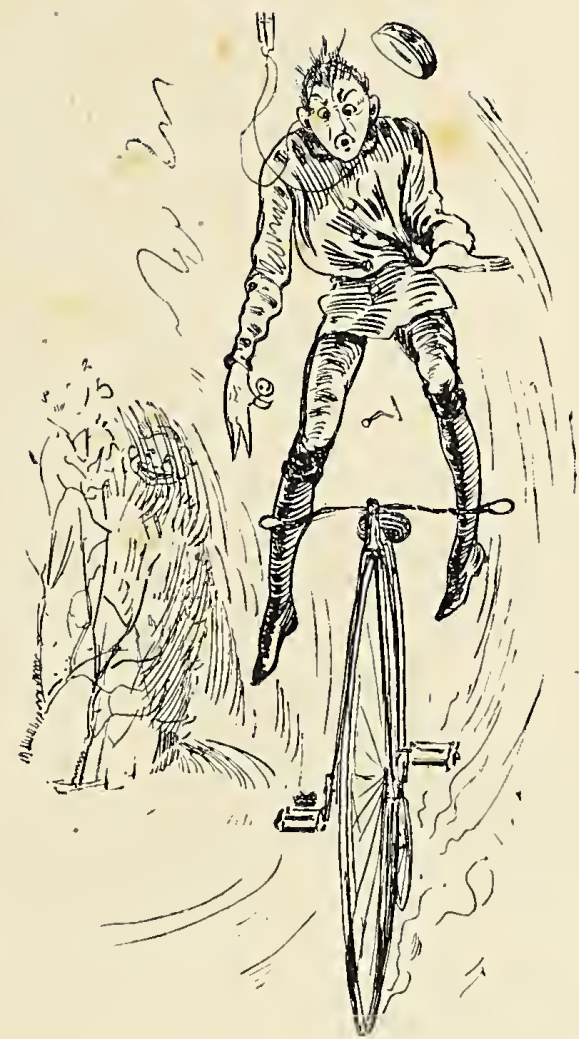

A mischievous urchin of Lynn, Concealed on a saddle a pin, And the poor rider's fright He observed with delight And a most diabolical grin. 


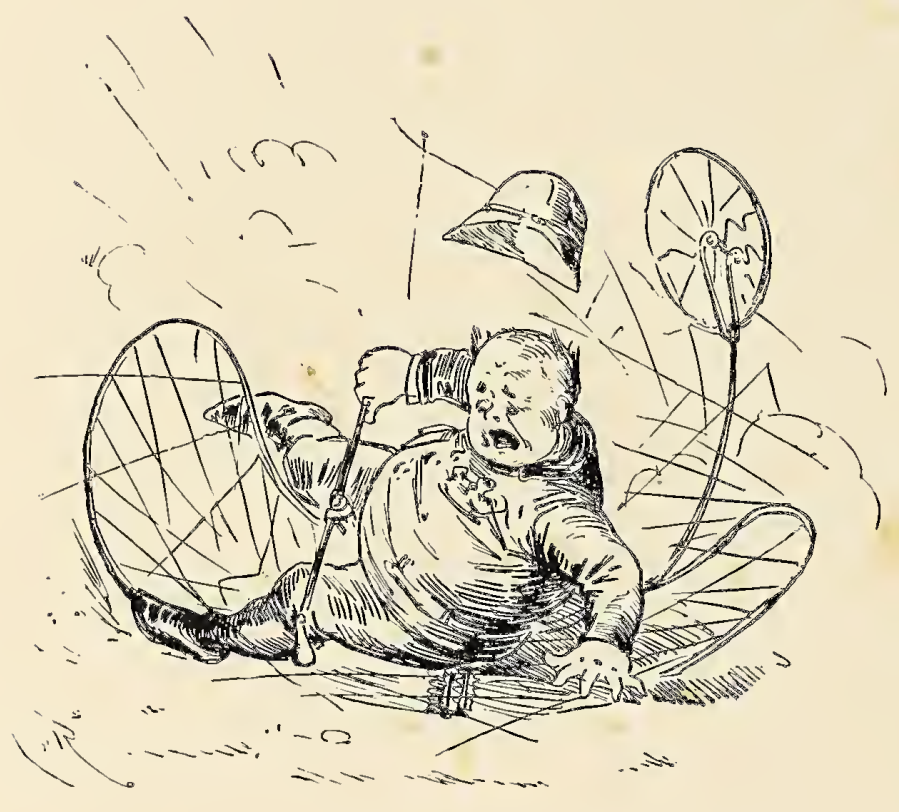

His weight was three hundred and forty;

He soberly said that he thought he

Ought to purchase a "Pacer,"

Or a light semi-racer, -

Good gracious! he oughtn't to, ought he? 


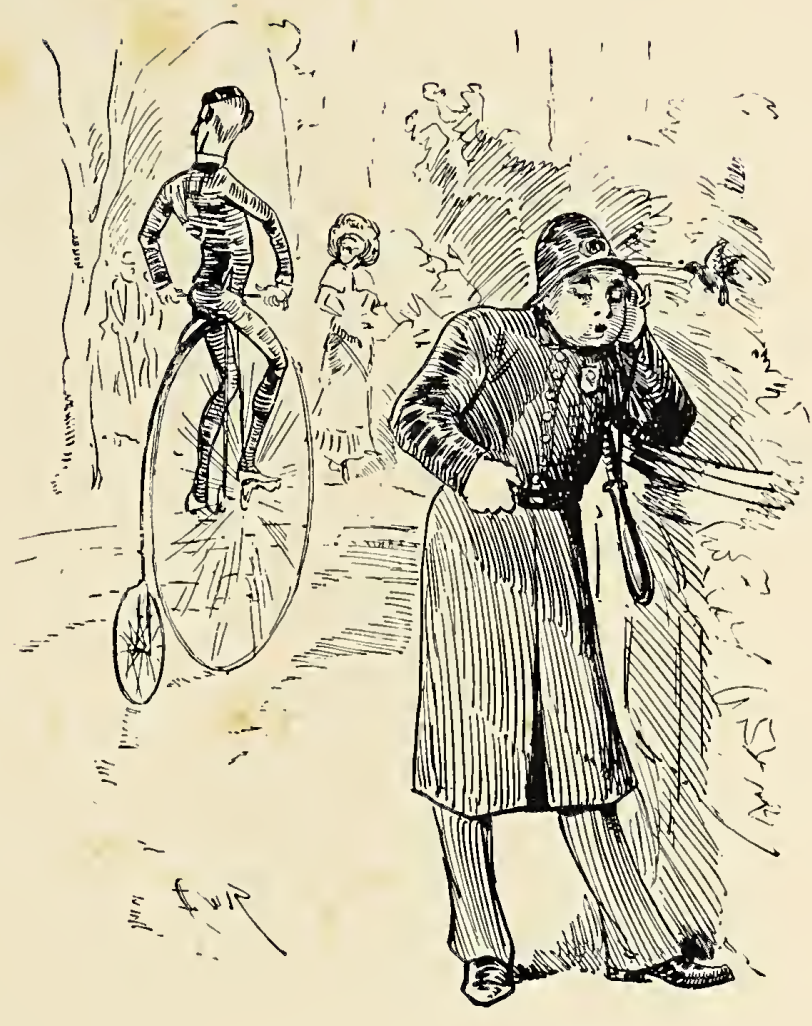

A wide-Awake, Central Park cop Excitedly told me to stop; When I fee-bly opposed The injunction, he dozed.

I rode thro' the Park. Do you drop? 


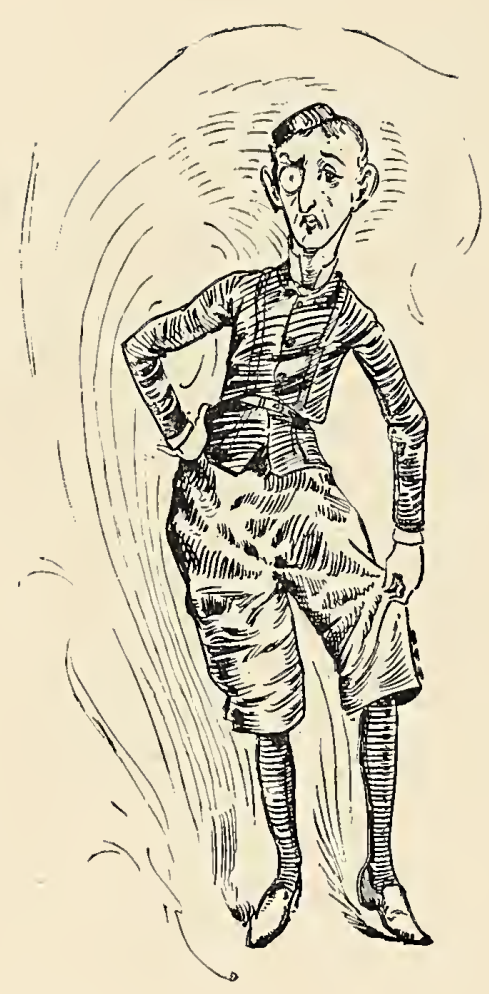

A SLIM-LOOKING youth of Manhattan

Bought bicycle breeks of tight pattern;

But he soon took 'em off,

And remarked with a cough,

"I think I will wait till I fatten." 


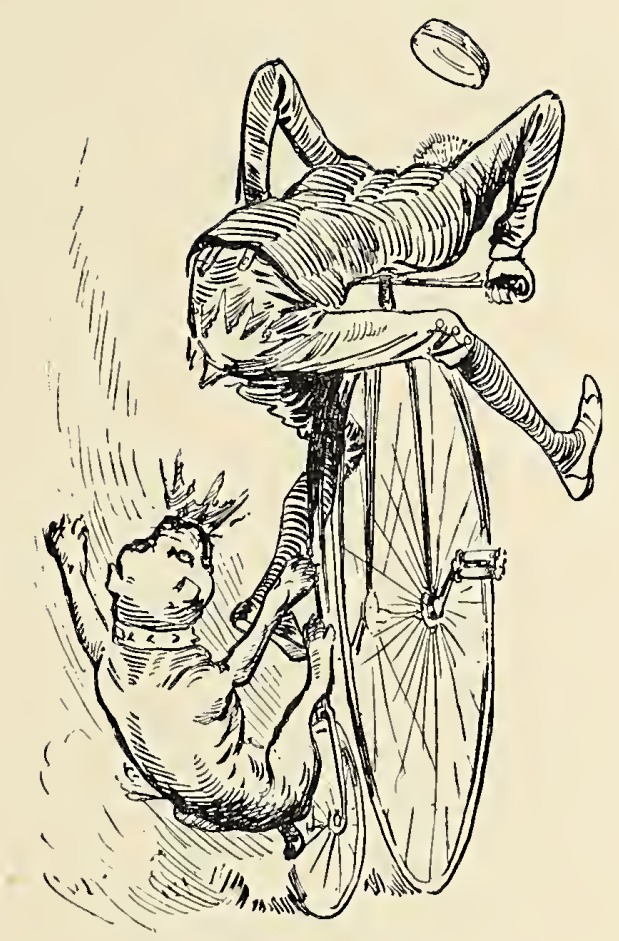

He had entered a bicycle match,

And was mounting his wheel at the scratch,

When a dog caught the slack

Of his breeches, alack!

And he now goes about with a patch. 


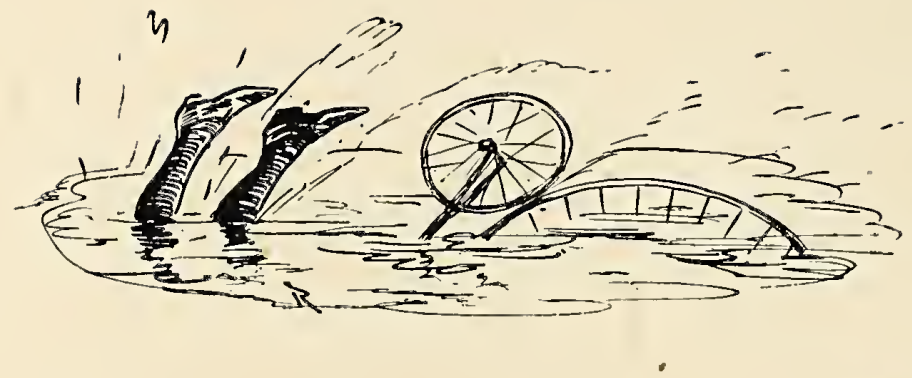

HE went for a peaceable roll;

His wheel took a piece of a hole,

And it soon came to pass

That a requiem mass

Was sung for the peace of his soul.

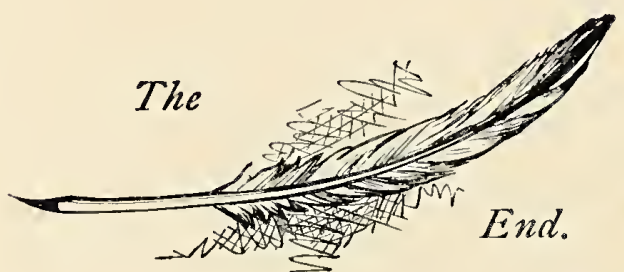









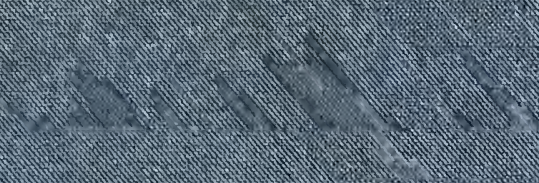
$a^{2}=$
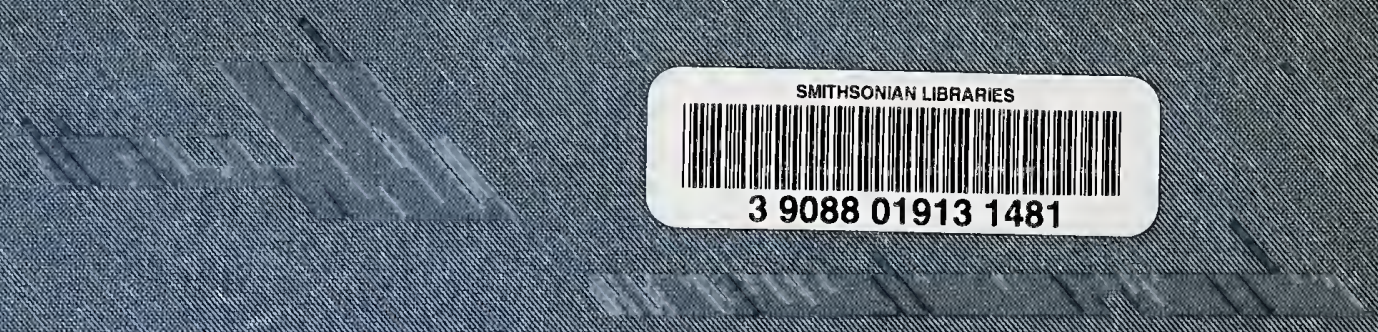

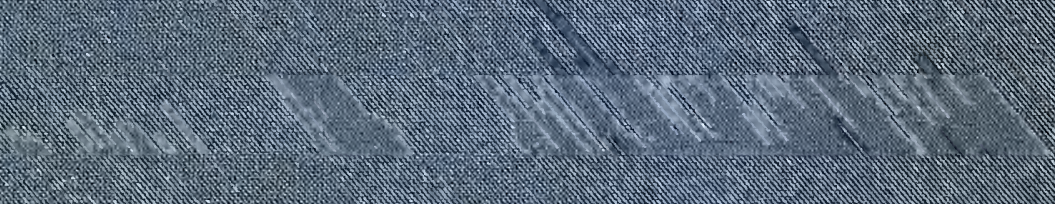

t.

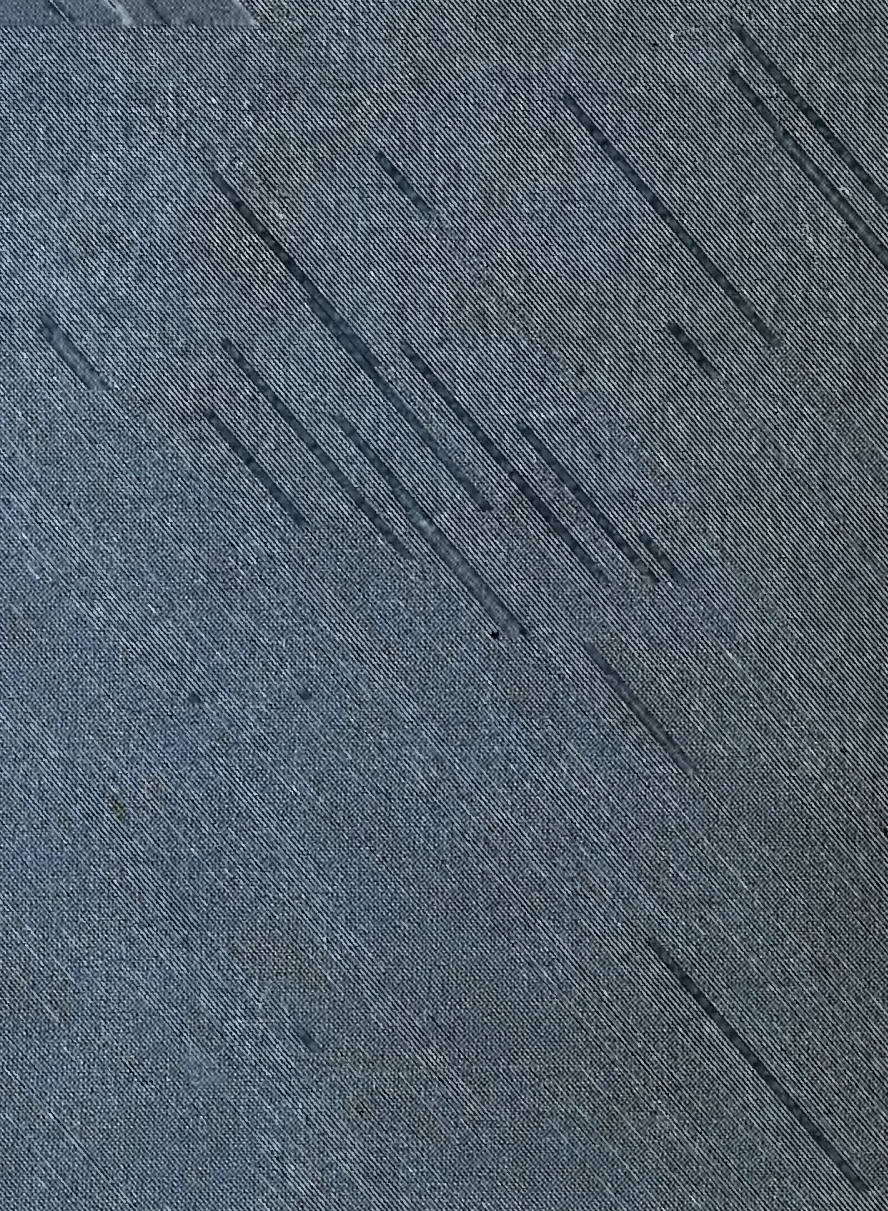

